\title{
Toll-Like Receptor Ligands and Interferon- $\gamma$ Synergize for Induction of Antitumor M1 Macrophages
}

\author{
Elisabeth Müller ${ }^{1,2 *}$, Panagiotis F. Christopoulos ${ }^{1}$, Sanjib Halder ${ }^{1}$, Anna Lunde', \\ Kahsai Beraki ${ }^{1}$, Martin Speth ${ }^{2}$, Inger Øynebråten ${ }^{1}$ and Alexandre Corthay ${ }^{1 *}$ \\ ${ }^{1}$ Tumor Immunology Lab, Department of Pathology, Rikshospitalet, Oslo University Hospital, University of Oslo, Oslo, \\ Norway, ${ }^{2}$ Department of Biosciences, University of Oslo, Oslo, Norway
}

OPEN ACCESS

Edited by: Renato Ostuni, San Raffaele Hospital (IRCCS), Italy

Reviewed by:

John P. Vasilakos, 3M Company, United States Jaya Talreja,

Wayne State University School of Medicine, United States

*Correspondence: Elisabeth Müller elisabeth.mueller@ibv.uio.no; Alexandre Corthay alexandre.corthay@ibv.uio.no

Specialty section: This article was submitted to Molecular Innate Immunity, a section of the journal Frontiers in Immunology

Received: 07 July 2017 Accepted: 06 October 2017 Published: 26 October 2017

Citation:

Müller E, Christopoulos PF, Halder S, Lunde A, Beraki K, Speth $M$,

Øynebråten I and Corthay A (2017)

Toll-Like Receptor Ligands and Interferon- $\gamma$ Synergize for Induction of Antitumor M1 Macrophages.

Front. Immunol. 8:1383. doi: 10.3389/fimmu.2017.01383
Tumor-associated macrophages may either promote or suppress tumor growth depending on their activation status. Interferon- $\gamma$ (IFN- $\gamma$ ) has been identified as a key factor for inducing tumoricidal M1 phenotype in macrophages. However, it remains unclear whether IFN- $\gamma$ is sufficient or if additional stimuli are required. Here, we tested IFN- $\gamma$ and a panel of toll-like receptor (TLR) agonists for the ability to activate murine macrophages toward a tumoricidal M1 phenotype. The following TLR ligands were used: TLR1/TLR2 agonist Pam3CSK4, TLR2/TLR6 agonist lipotechoic acid, TLR3 agonist poly(l:C), TLR4 agonist lipopolysaccharide (LPS), TLR5 agonist flagellin, TLR7 agonist CL264, and TLR9 agonist $\mathrm{CpG}$. We used an in vitro growth inhibition assay to measure both cytotoxic and cytostatic activity of mouse macrophages against Lewis lung carcinoma (LLC) and MOPC315 plasmacytoma tumor cells. Production of nitric oxide (NO) and cytokines by activated macrophages was quantified. We found that IFN- $\gamma$ alone was not able to render macrophages tumoricidal. Similarly, macrophage activation with single TLR agonists was inefficient. In sharp contrast, IFN- $\gamma$ was shown to synergize with TLR agonists for induction of macrophage tumoricidal activity and production of both NO and pro-inflammatory cytokines (TNF- $\alpha, \mathrm{IL}-12 \mathrm{p} 40$, and IL-12p70). Furthermore, IFN- $\gamma$ was shown to suppress macrophage IL-10 secretion induced by TLR agonists. NO production was necessary for macrophage tumoricidal activity. We conclude that two signals from the microenvironment are required for optimal induction of antitumor M1 macrophage phenotype. Combination treatment with IFN- $\gamma$ and TLR agonists may offer new avenues for macrophage-based cancer immunotherapy.

Keywords: macrophages, tumoricidal, toll-like receptors, interferon- $\gamma$, cancer, nitric oxide, immunotherapy

\section{INTRODUCTION}

Macrophages are multifunctional cells whose activities are triggered in response to stimuli from the microenvironment. The stroma of solid tumors contains tumor-associated macrophages (TAMs) which may either suppress or promote tumor development depending on their activation phenotype $(1,2)$. According to a widely used nomenclature, macrophages with antitumor or

\footnotetext{
Abbreviations: BMDM, bone marrow derived macrophage; cpm, counts per minute; DETA/NO, diethylenetriamine/NO adduct; FBS, fetal bovine serum; FLA, flagellin; IFN- $\gamma$, interferon- $\gamma$; iNOS, inducible nitric oxide synthase; LLC, Lewis lung carcinoma; LPS, lipopolysaccharide; LTA, lipotechoic acid; MAF, macrophage-activating factor; MIG, monokine-induced by IFN- $\gamma$; NFkB, nuclear factor kappa-light-chain-enhancer of activated B cells; NO, nitric oxide; Pam3, Pam3CSK4; Poly(I:C), polyinosinic:polycytidylic acid; SMT, s-methylisothiourea hemisulfate salt; TLR, toll-like receptor; TAM, tumor-associated macrophage.
} 
killing activity are called M1 while tumor-promoting or healing macrophages are named M2 or M2-like $(3,4)$. Because TAMs are commonly assumed to have a tumor-promoting phenotype, research in the field has mainly focused on detrimental aspects of macrophages in tumors (5) and therapeutic strategies were designed accordingly for the depletion of TAMs (6). However, it has also been reported that TAMs may be rendered tumoricidal upon activation by tumor-specific Th1 cells (7). Furthermore, several recent reports revealed the potential of re-programming TAMs toward a tumoricidal M1 phenotype rather than depleting them (8-10). Therefore, it is of therapeutic importance to clarify the molecular requirements for activation of macrophages toward an antitumor M1 phenotype.

Antitumor M1-polarized macrophages are characterized by their direct cytostatic and cytotoxic effect on tumor cells, secretion of pro-inflammatory cytokines, and stimulation of $\mathrm{T}$ cell immunity $(7,11,12)$. The ability of macrophages to kill tumor cells in vitro was reported already in 1970 (13), and it was shown that supernatant of spleen cells from tumor-immunized mice contained a factor that could render macrophages tumoricidal in vitro (14). Investigations into the cooperation of lymphoid cells and macrophages led to the identification of interferon- $\gamma$ (IFN- $\gamma$ ), previously known as macrophage-activating factor (MAF), as a major agent responsible for regulating macrophage tumoricidal activity $(15,16)$. Bacterial endotoxin [lipopolysaccharide (LPS)] and viral RNA were also reported to render macrophages cytotoxic to tumor cells (17). Later studies suggested that IFN- $\gamma$ may not be sufficient to render macrophages tumoricidal and that a second signal from the microenvironment was required $(18,19)$. Dead bacteria or purified LPS were shown to provide such a second signal to render macrophages tumoricidal in combination with IFN- $\gamma(20-22)$. Still, many current reviews refer to IFN- $\gamma$ as the major inducer of tumoricidal M1 macrophages or do not make a distinction between the phenotype resulting from activation with IFN- $\gamma$ alone, LPS alone or both factors $(23,24)$. A popular view is that activation of M1/M2 macrophage phenotypes depend on cytokines from adaptive immune cells (such as IFN- $\gamma$ from Th1 cells or IL-4 from Th2 cells), rather than signals from innate receptors such as toll-like receptors (TLRs) (25). There is confusion regarding the current annotation of macrophage phenotype and the M1/M2 classification has been criticized $(24,26)$. Recent studies investigating macrophage activation do not describe the direct tumoricidal activity of macrophages, but rather focus on production of cytokines, nitric oxide $(\mathrm{NO})$ and reactive oxygen species, and changes in gene expression or surface markers (27, 28). As a result, it remains unclear whether IFN- $\gamma$ is sufficient or if additional stimuli such as LPS are required for induction of tumoricidal M1 macrophages.

Lipopolysaccharide binds to TLR4, a member of the TLR family of receptors which recognize pathogen- and damage-associated molecular pattern molecules. These receptors signal through adaptor molecules and downstream mediators to modulate gene transcription and induce a pro-inflammatory response. The great potency of LPS in stimulating immune responses has led to clinical trials investigating the use of LPS against cancer. Unfortunately, severe side effects have been reported and therapeutic use of LPS against cancer has so far not been approved (29). However, TLR4 agonists different from LPS as well as agonists of other TLRs have been investigated for their potential use in cancer therapy, either as vaccine adjuvants or immune modulators (30). Several TLR agonists have been shown to activate macrophages similarly to LPS, inducing cytokine production, upregulation of antigenpresentation and co-stimulatory molecules, and induction of the enzyme inducible NO synthase (iNOS) with resulting NO production $(31,32)$. Viral double stranded RNA, an agonist of TLR3, was shown to induce tumoricidal activity in macrophages already in the 1970s (17), and a synthetic analog, poly(I:C), was also efficient (33). Other TLR agonists that have shown potency for induction of antitumor M1 macrophages includes lipotechoic acid (LTA) (34), gardiquimod (35), R848 (36), and CpG (37). However, none of these studies investigated the role of IFN- $\gamma$ in potentiating the effect of the TLR agonists despite accumulating evidence for the strong synergistic effect of this cytokine on TLR signaling. Furthermore, the experimental setup, including the source of macrophages, the functional assay used, and the activation regimen with single or combination treatment varied greatly between these studies. This makes it difficult to conclude on the background of the current literature as to which TLRs are effective in inducing tumoricidal M1 macrophages and whether IFN- $\gamma$ is important for such activation.

This prompted us to systematically test a range of TLR agonists in functional assays for M1 polarization of mouse macrophages, including tumoricidal activity, and to test the synergistic effect of IFN- $\gamma$ when combined with LPS or other TLR agonists. We found that several TLR agonists could induce macrophage-mediated tumor cell growth inhibition, but only when combined with IFN- $\gamma$. IFN- $\gamma$ synergized with all TLR agonists for NO production and secretion of pro-inflammatory and Th1-polarizing (IL-12p70) cytokines. We conclude that optimal activation of antitumor M1 macrophages require two signals, which can be provided by a combination of IFN $-\gamma$ and TLR agonists. Seven TLR agonists were shown to be effective and thereby emerge as potential therapeutic agents for cancer immunotherapy based on targeting of TAMs.

\section{MATERIALS AND METHODS}

\section{Mice}

C57BL/6NRj mice from Janvier Labs (Le Genest-Saint-Isle, France) were bred at the Department of Comparative Medicine, Oslo University Hospital, Rikshospitalet (Oslo, Norway) in specific pathogen free conditions. The study was approved by the Norwegian National Committee for Animal Experiments. All experiments were performed in accordance with the institutional guidelines and regulations, including EU directive 2010/63/EU.

\section{Cell Lines}

MOPC315 is a mineral-oil induced plasmacytoma cell line which was derived from a BALB/c mouse and was purchased from the American Type Culture Collection (ATCC, Manassas, VA, USA) (38). Lewis lung carcinoma (LLC, also called LLC1) is a cell line originating from a spontaneous lung carcinoma in a C57BL/6 mouse and was obtained from CLS Cell Lines Service (Eppelheim, Germany) (39). L929 is a fibroblast-like cell line 
originating from connective tissue of a $\mathrm{C} 3 \mathrm{H} / \mathrm{An}$ mouse and was obtained from ATCC (40). J774.A1 is a macrophage-like cell line originating from the ascites of a BALB/c mouse with reticulum cell sarcoma and was kindly given by Anders $\varnothing$. Gammelsrud at the Norwegian Veterinary Institute (Oslo, Norway) (41). All of the above described cell lines were negative for mycoplasma infection as tested by use of MycoSensor PCR Assay kit (\#302109, Agilent, Santa Clara, CA, USA).

\section{Generation of Bone Marrow Derived Macrophages}

Confluent L929 cells were cultured in RPMI 1640 medium (\#61870044, Thermo Fisher Scientific, Waltham, MA, USA) containing 10\% fetal bovine serum (FBS, \#BCHRS0405, Biochrom $\mathrm{GmbH}$, Berlin, Germany) for 10 days before the medium was centrifuged, filtered and stored at $-20^{\circ} \mathrm{C}$. Such L929 cell-conditioned medium contains macrophage colony-stimulating factor and was used for induction of macrophage differentiation according to standard protocols (42). Femurs and tibiae of the hind legs from 8 - to 12 -week-old male and female C57BL/6NRj mice were harvested and flushed with RPMI 1640 medium containing 10\% FBS under sterile conditions. The isolated bone marrow was passed through a cell strainer with $70-\mu \mathrm{m}$ pores (\#CLS431751-50EA, Sigma-Aldrich, St. Louis, MO, USA) and cultured in $15 \mathrm{~mm}$ non-tissue culture treated dishes (\#734-2359, VWR, Radnos, PA, USA) in RPMI 1640 medium containing 30\% L929-derived conditioned medium. The bone marrow cells were cultured for 5 days, after which non-adherent, cells were washed off using phosphate buffered saline (PBS, \# D8662, Sigma-Aldrich) and the adherent macrophages were cultured for 1 more day. Macrophages were harvested by incubation for $30 \mathrm{~min}$ at $4^{\circ} \mathrm{C}$ with cold PBS without $\mathrm{CaCl}_{2}$ and $\mathrm{MgCl}_{2}$ (\#D8537, Sigma-Aldrich). Macrophages were then flushed off the plate, collected and kept frozen in aliquots at $-150^{\circ} \mathrm{C}$ in FBS with $10 \%$ dimethyl sulfoxide (\#0231-500 ml, VWR) for future experiments. The purity of the cells was $99 \%$ when analyzed by flow cytometry using the macrophage markers CD11b (\#101219, BioLegend, San Diego, CA, USA) and F4/80 (\#123116, BioLegend), and the cells were then referred to as bone marrow derived macrophages (BMDMs).

\section{Tumor Cell Growth Inhibition Assay}

Bone marrow derived macrophages were thawed and cultured for 3 days in non-tissue culture treated dishes (VWR) in RPMI 1640 medium containing 10\% FBS and 10\% L929-derived conditioned medium. The BMDMs were harvested by scraping, incubated for $2 \mathrm{~h}$ at $37^{\circ} \mathrm{C}$ with $10 \mathrm{mg} / \mathrm{ml}$ mitomycin C (\#M4287, SigmaAldrich) to inhibit proliferation, and then washed thoroughly. Next, the BMDMs were resuspended in medium and seeded out in triplicates in flat bottom 96 well plates (\#734-1793, Costar, Washington, DC, USA) at 3 cell densities: $6 \times 10^{4}, 3 \times 10^{4}$, and $3 \times 10^{3}$ cells/well in a final volume of $200 \mu \mathrm{l} /$ well. After $24 \mathrm{~h}$ of incubation, the medium was replaced with medium containing various stimuli, see section below, and incubated for another $24 \mathrm{~h}$. Then, half of the cell supernatants $(100 \mu \mathrm{l})$ were removed and used for quantification of $\mathrm{NO}_{2}{ }^{-}$. Target cell suspensions, consisting of 5,000 cells/well of MOPC315 or 3,000 cells/well of LLC cells were added, resulting in varying ratios of effector to target cells. After $24 \mathrm{~h}$ of co-culture, cells were pulsed with $\left[{ }^{3} \mathrm{H}\right]$ thymidine (\#MT6032, Hartmann Analytic, Braunschweig, Germany) and harvested $18 \mathrm{~h}$ later by a freeze and thaw cycle. The amount of radiolabeled DNA was measured on a 1450 MicroBeta Trilux Microplate Scintillation counter (Perkin Elmer, Waltham, MA, USA). The same assay was performed using the cell line J774.A1 as effector cells instead of BMDMs. Mitomycin C $(10 \mathrm{mg} / \mathrm{ml})$ was also used to block proliferation of J774.A1 cells before they were seeded out in 96 well plates in triplicates at a density of $1 \times 10^{5}$ cells/well in a final volume of $200 \mu \mathrm{l} /$ well.

For the purpose of statistical analysis of pooled data from several experiments, the percentage of remaining cancer cell growth was calculated by dividing counts per minute (cpm) values from the macrophage-LLC co-cultures at the 20:1 ratio with the cpm values of the corresponding wells with LLCs alone using the following equation:

$$
\frac{\mathrm{cpm}_{20: 1}}{\mathrm{cpm}_{\text {LLC alone }}} \times 100=\% \text { growth remaining. }
$$

\section{TLR Agonists and Cytokines}

The following TLR agonists were used: TLR1/TLR2 agonist Pam3CSK4 (Pam3, \#tlrl-pms, InvivoGen, San Diego, CA, USA); TLR3 agonist poly(I:C) of high molecular weight type (\#trl-pic, InvivoGen); TLR4 agonist LPS from E. coli (\#L4391, SigmaAldrich); TLR5 agonist flagellin (FLA) from S. typhimurium, ultrapure type (\#tlrl-epstfla-5, InvivoGen); TLR2/TLR6 agonist LTA from S. aureus (\#L2515, Sigma-Aldrich); TLR7 agonist CL264 (\#tlrl-c264e-5, InvivoGen); and TLR9 agonist CpG, class C ODN 2395 (\#tlrl-2395-1, InvivoGen). The TLR agonists were used alone or in combination with mouse recombinant IFN- $\gamma$ (\#315-05, Peprotech, Rocky Hill, NJ, USA) at a $40 \mathrm{ng} / \mathrm{ml}$ concentration.

\section{Quantification of Nitrite by the Griess Test} Supernatants were centrifuged at $410 \mathrm{~g}$ to remove cellular debris and immediately assayed for nitrite as a measure for the amount of NO that was produced. $50 \mu \mathrm{l}$ of macrophage supernatant was added to $50 \mu \mathrm{l}$ of Griess reagent A consisting of distilled water with $1 \%$ sulphanilamide (\#S9251, Sigma-Aldrich) and $5 \%$ phosphoric acid (\#W290017, Sigma-Aldrich). The mixture was incubated in the dark for $10 \mathrm{~min}$. Next, $50 \mu \mathrm{l}$ of Griess reagent $\mathrm{B}$ consisting of $0.1 \% \mathrm{~N}$-(1-napthyl) ethylenediamine (\#N9125, Sigma-Aldrich) in distilled water was added and the absorbance at $540 \mathrm{~nm}$ was measured with a microplate reader (BioTek Instruments, Winooski, VT, USA). Serial dilution of $\mathrm{NaNO}_{2}$ served to create a standard curve of nitrite in the range of $1.56-100 \mu \mathrm{M}$.

\section{iNOS Inhibition and NO Donor}

S-Methylisothiourea hemisulfate salt (SMT, \#M84445, SigmaAldrich) is a potent inhibitor of iNOS (43) which was used to block the production of $\mathrm{NO}$ by activated macrophages. Diethylenetriamine/NO adduct (DETA/NO) (\#D185, SigmaAldrich) was used to produce controlled release of NO in solution. 


\section{Cytokine Quantification by Luminex Technology}

Supernatants harvested from macrophages that had been stimulated with TLR agonists and/or IFN- $\gamma$ for $24 \mathrm{~h}$ were centrifuged to remove cellular debris and stored at $-80^{\circ} \mathrm{C}$ for maximum 1 week and assayed for cytokines. The cytokine concentrations were determined by multiplex bead assays, Bio-Plex Pro Mouse cytokine singleplex sets for TNF- $\alpha$ (\#171-G5023M), IL-12p40 (\#171-G5010M), IL-12p70 (\#171-G5011M), monokine-induced by IFN- $\gamma$ (MIG) (\#171-G6005M), and IL-10 (\#171-G5009M) from Bio-Rad Laboratories (Hercules, CA, USA) according to the manufacturer's instructions. Samples in duplicates were analyzed, using a Bio-Plex MAGPIX Multiplex Reader and Bio-Plex Manager 6.1 software (Bio-Rad Laboratories).

\section{Statistical Analysis}

Multiple groups were compared by using one-way ANOVA followed by a post hoc Tukey test for multiple comparisons and $p$ values of less than 0.05 were considered statistically significant $\left({ }^{\star} p\right.$-value $<0.05,{ }^{* *} p$-value $<0.01,{ }^{* * *} p$-value $\left.<0.001\right)$. Statistical analysis, including column statistics, was performed using GraphPad Prism 7.02 software.

\section{RESULTS}

\section{LPS and IFN- $\gamma$ Synergize to Activate Macrophages to Inhibit Tumor Cell Growth}

Table 1 shows an overview of the literature on induction of tumoricidal activity of macrophages by various TLR agonists. The most widely used agonist, LPS, has shown effect in a number of studies that utilized different functional assays, macrophages and target cells. LPS has been used alone, in combination with MAF/IFN- $\gamma$, other TLR agonists, agonistic anti-CD40 antibodies, or TGF- $\beta$ inhibition. However, basic questions regarding the induction of tumoricidal activity in normal macrophages remain to be answered. Many of the studies from the 1970s and 1980s lacked reliably pure (LPS free) reagents or macrophages, and more recent articles typically lack functional assays for tumoricidal activity.

We used an in vitro growth inhibition assay $(7,13)$ in order to measure both the cytotoxic and cytostatic activity of macrophages toward tumor cells (Figure 1A). Macrophages were first treated with the DNA crosslinker mitomycin $\mathrm{C}$ to block cell division and thereby avoid that macrophage growth could interfere with the detection of tumor cell growth inhibition. Thereafter, macrophages

TABLE 1 | Literature on induction of macrophage tumoricidal activity by TLR agonists.

\begin{tabular}{|c|c|c|c|c|c|}
\hline TLR agonist & Functional assay used & Effector cells & Target cells & Conclusion & Ref \\
\hline $\begin{array}{l}\text { Lipopolysaccharide (LPS), } \\
\text { lipid A (TLR4), RNA, and } \\
\text { poly(I:C) (TLR3) }\end{array}$ & Gl by manual counting of cells & $\begin{array}{l}\text { PM from DBA } 2 \text { or } \mathrm{CBA} \\
\text { mice }\end{array}$ & L5178Y & $\begin{array}{l}\text { All agents induced tumoricidal activity in } \\
\text { macrophages }\end{array}$ & $(17)$ \\
\hline LPS & $\begin{array}{l}\text { Gl by cell number, cell death by } \\
\text { release of thymidine }\end{array}$ & $\begin{array}{l}\mathrm{PM} \text { from } \mathrm{C} 3 \mathrm{H} / \mathrm{HeN} \text {, } \\
\mathrm{C} 3 \mathrm{H} / \mathrm{HeJ} \text { mice }\end{array}$ & 3T12 & $\begin{array}{l}\text { LPS induced tumoricidal activity, and } \\
\text { MAF acted synergistically }\end{array}$ & (20) \\
\hline LPS & Cell death by thymidine labeling & $\begin{array}{l}\text { Human macrophages from } \\
\text { PBMCs }\end{array}$ & SK-BR-3 and HT-29 & $\begin{array}{l}\text { LPS induce tumoricidal activity, and } \\
\text { MAF acted synergistically }\end{array}$ & $(44)$ \\
\hline $\begin{array}{l}\text { Lipotechoic acid (LTA) } \\
\text { (TLR2/6), lipomannan (TLR2) }\end{array}$ & Cell death by release of thymidine & $\begin{array}{l}\text { Bone marrow derived } \\
\text { macrophages from DA rats }\end{array}$ & $\begin{array}{l}\text { P-815 and DA tumor } \\
\text { cells }\end{array}$ & $\begin{array}{l}\text { Some LTAs induced strong tumoricidal } \\
\text { activity, other LTAs and lipomannan less }\end{array}$ & $(34)$ \\
\hline LPS, CpG (TLR9) & $\begin{array}{l}\text { Gl by thymidine labeling and cell } \\
\text { death by flow cytometry }\end{array}$ & $\begin{array}{l}\mathrm{PM} \text { from C3h/HeJ, CB17 } \\
\text { SCID/beige or C57BL/6 } \\
\text { mice }\end{array}$ & $\begin{array}{l}\text { L5178Y, B16, RENCA, } \\
\text { M21, NXS2, OVCAR }\end{array}$ & $\begin{array}{l}\text { CpG and LPS combined or either } \\
\text { factor combined with in vivo anti-CD40 } \\
\text { ligation induced tumoricidal activity }\end{array}$ & $(45)$ \\
\hline LPS, BCG & $\begin{array}{l}\text { Cell death by chrome release } \\
\text { assay }\end{array}$ & PM from $\mathrm{C} 3 \mathrm{H} / \mathrm{HeN}$ mice & MBT-2 & $\begin{array}{l}\text { Both LPS and BCG induced tumoricidal } \\
\text { activity }\end{array}$ & $(46)$ \\
\hline LPS, CpG & $\begin{array}{l}\text { Gl by thymidine labeling and cell } \\
\text { death by flow cytometry }\end{array}$ & PM from C57BL/6 mice & $\begin{array}{l}\text { B16, L5178Y and } \\
\text { NXS2 }\end{array}$ & $\begin{array}{l}\text { In vivo stimulation with } \mathrm{CpG} \text { induced } \\
\text { tumoricidal activity in vitro, which was } \\
\text { improved by adding LPS }\end{array}$ & $(47)$ \\
\hline Poly(l:C) & $\begin{array}{l}\text { Cell death by chrome release } \\
\text { assay }\end{array}$ & $\begin{array}{l}\text { Tumor-associated } \\
\text { macrophages (TAMs) from } \\
\text { C57BL/6 mice }\end{array}$ & 3LL Lewis & $\begin{array}{l}\text { In vivo poly(l:C) induced in vitro } \\
\text { tumoricidal activity }\end{array}$ & (33) \\
\hline LPS, CpG & Gl by thymidine labeling & PM from C57BL/6 mice & B16 & $\begin{array}{l}\text { LPS synergized with in vivo stimulation } \\
\text { with anti-CD } 40 \text { and } \mathrm{CpG} \text { to induce } \\
\text { in vitro tumoricidal activity }\end{array}$ & $(48)$ \\
\hline LPS, gardiquimod (TLR7) & Cell death by assay for luciferase & $\begin{array}{l}\text { CD11b+ CD11 } \mathrm{c}^{-} \text {TAMs } \\
\text { from C57/BL6 mice }\end{array}$ & MN/MCA1 & $\begin{array}{l}\text { TGF- } \beta \text { inhibition combined with TLR4 } \\
\text { or TLR7 ligation induced tumoricidal } \\
\text { activity }\end{array}$ & $(35)$ \\
\hline $\begin{array}{l}\text { R848 (TLR7/8), Pam3 } \\
\operatorname{TLR}(1 / 2)\end{array}$ & Cell death by flow cytometry & $\begin{array}{l}\text { mMDCs from human } \\
\text { PBMCs }\end{array}$ & A549 & $\begin{array}{l}\text { R848 induced tumoricidal activity, } \\
\text { but not Pam3 }\end{array}$ & $(36)$ \\
\hline
\end{tabular}

Gl, growth inhibition; PM, peritoneal macrophages; ds, double stranded; MAF, macrophage-activating factor (interferon- $\gamma$ ); PBMCs, peripheral blood mononuclear cells; BCG, Bacillus Calmette-Guérin; TGF- $\beta$, tumor necrosis factor beta; iNOS, inducible nitric oxide synthase; mMDCs, monocytic myeloid-derived suppressor cells. 


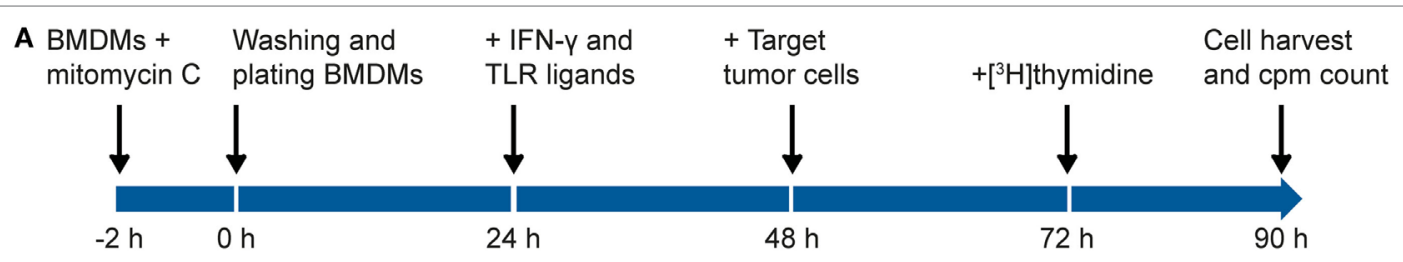

B

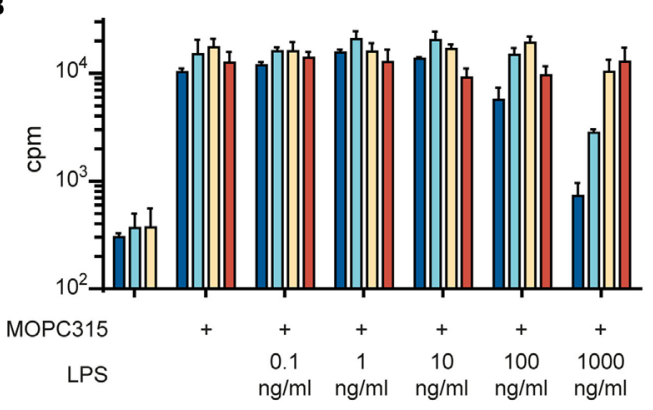

C

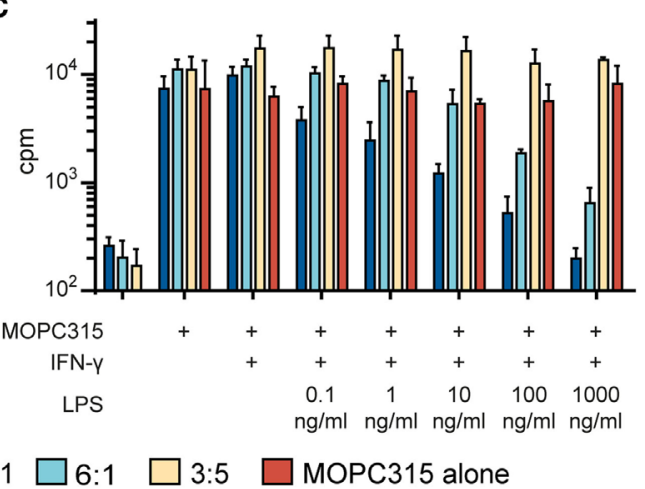

FIGURE 1 | Lipopolysaccharide (LPS) and IFN- $\gamma$ synergize to induce tumoricidal activity in macrophages. (A) Time-line for the growth inhibition assay used for measuring macrophage cytotoxic and cytostatic activity toward tumor cells. (B) Mitomycin C-treated bone marrow derived macrophages (BMDMs) were stimulated for $24 \mathrm{~h}$ with various LPS concentrations before addition of 5,000 MOPC315 tumor cells/well, resulting in the indicated macrophage to target cell ratios. The growth of the tumor cells was quantified by measuring incorporation of radiolabeled thymidine and is shown on the $y$-axis as mean counts per minute (cpm) values of triplicates \pm SD. The three columns to the left show proliferation of BMDMs alone (tumor cells were not added). (C) BMDMs were stimulated with IFN- $\gamma$ (40 ng/ml) in combination with different concentrations of LPS for $24 \mathrm{~h}$ before target cells were added. Radiolabeled thymidine incorporation in growing cells is shown on the $y$-axis as mean cpm values of triplicates \pm SD. The three columns on the left show proliferation of BMDMs alone. (B,C) All experiments were performed three times and representative experiments are shown.

were cultivated in the presence or absence of IFN- $\gamma$ and TLR agonists for $24 \mathrm{~h}$, before tumor cells were added and co-cultured for $42 \mathrm{~h}$. Radiolabeled thymidine was used to detect tumor cell growth and was added to the co-cultures $18 \mathrm{~h}$ before cell harvest. As inhibition of tumor cell growth is known to depend on the number and density of macrophages, we seeded out macrophages in three different cell concentrations while the number of tumor cells remained constant within an experiment. The resulting ratio of macrophages to tumor cells, i.e., ratio of effector to target cells varied from 20:1 to 1:1 in various experiments.

In the first set of experiments, we investigated the effect of the classical macrophage activators IFN- $\gamma$ and LPS. We used C57BL/6-derived BMDM as a source of normal mouse macrophages and the MOPC315 plasmacytoma as target tumor cells. When used alone, a high concentration $(1,000 \mathrm{ng} / \mathrm{ml})$ of LPS was required to activate $\mathrm{BMDMs}$ for inhibition of MOPC315 cell growth (Figure 1B). The potency of LPS was greatly improved when the macrophages were stimulated with LPS in combination with IFN- $\gamma$ (Figure 1C) in accordance with previous reports $(20,22)$. Notably, macrophage stimulation with IFN- $\gamma$ alone had no inhibitory effect on tumor cell growth (Figure 1C). Taken together, the experiments showed that activation with both LPS and IFN- $\gamma$ was required for optimal induction of tumoricidal activity in macrophages. LPS alone could induce tumoricidal M1 macrophages, but only at high concentrations, while stimulation with IFN- $\gamma$ alone had no effect.

\section{Several TLR Agonists Other than LPS Synergize with IFN- $\gamma$ for Rendering Macrophages Tumoricidal}

To explore the potential of other natural or synthetic TLR agonists for inducing tumoricidal M1 macrophage phenotype, we tested a panel of agonists targeting different TLRs. In these experiments, the Lewis lung carcinoma (LLC) cell line was used as target cell line anticipating that macrophage-mediated tumor cell growth inhibition was not restricted to a single cell line. The target tumor cells were added to BMDMs activated by the following TLR agonists; TLR1/2 agonist Pam3, TLR2/6 agonist LTA, TLR3 agonist poly(I:C), TLR5 agonist flagellin, TLR7 agonist CL264, and TLR9 agonist CpG (Figures 2A-F). Pam3 was very potent at stimulating the BMDMs and it resulted in strong growth inhibition of LLC cells, even at concentrations as low as $1 \mathrm{ng} /$ $\mathrm{ml}$, but only when it was used together with IFN- $\gamma$ (Figure 2A). Similarly, IFN- $\gamma$ in combination with LTA (Figure 2B), CL264 (Figure 2E), and CpG (Figure 2F) induced tumor cell growth inhibition by BMDMs. Stimulation of BMDMs with poly(I:C) resulted in growth inhibition both alone and together with IFN- $\gamma$. Similar to LPS, the effect of poly(I:C) was potentiated by IFN- $\gamma$ (Figure 2C). Stimulation of BMDM with flagellin yielded no growth inhibition (Figure 2D). Statistical analysis was performed for two TLR agonists (Pam3 and $\mathrm{CpG}$ ) by pooling data from experimental repeats. Because baseline cpm values varied between experiments, the percentage of growth remaining was 

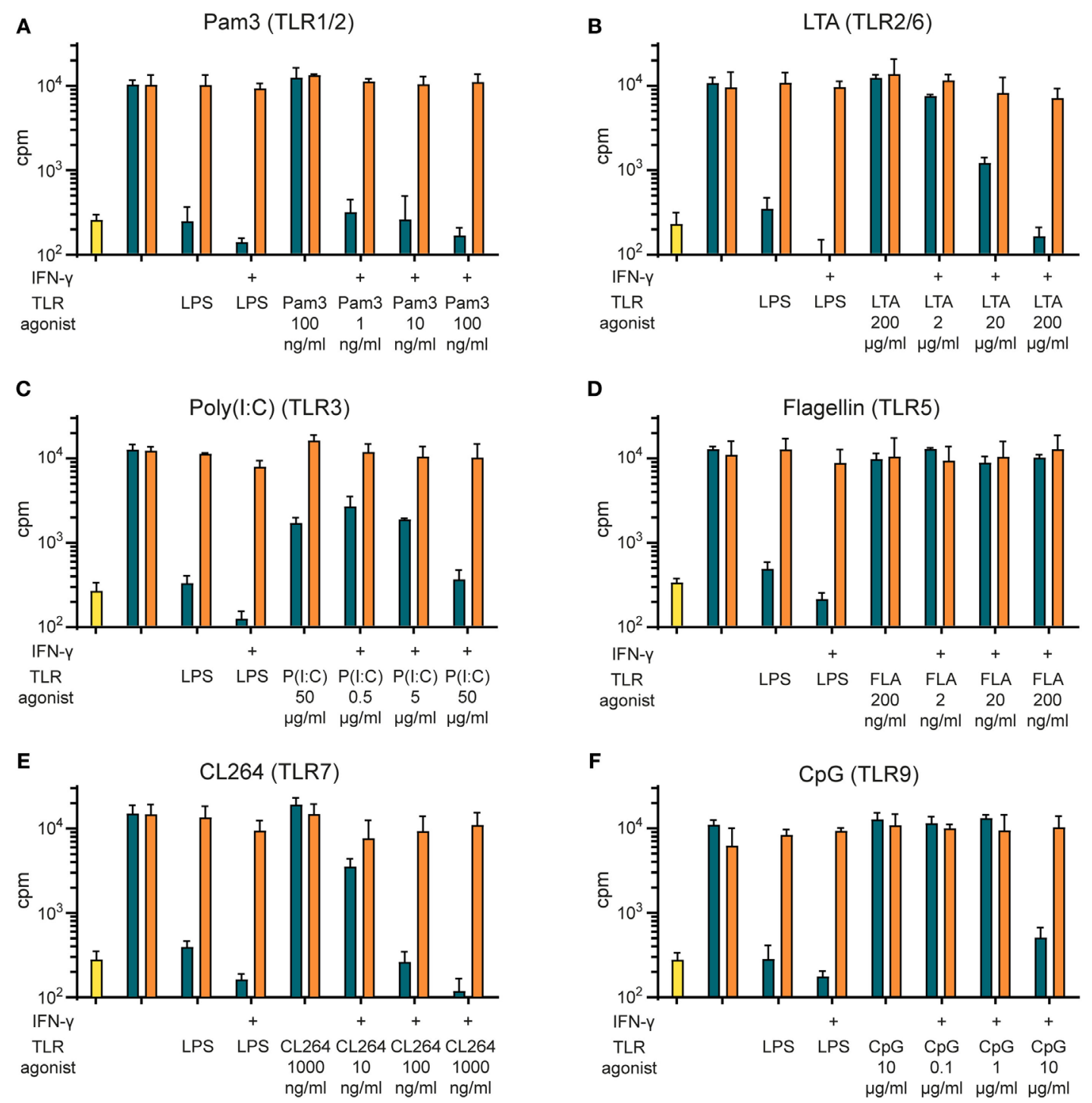

Macrophages alone $\square$ Macrophages+LLC (20:1 ratio) $\square$ LLC alone

G

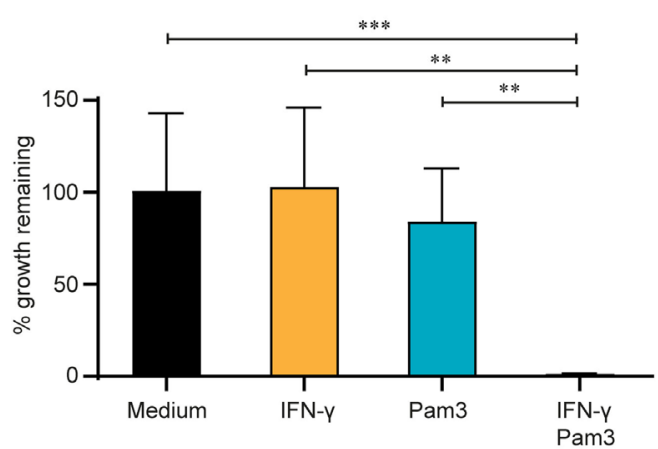

H

CpG (TLR9)

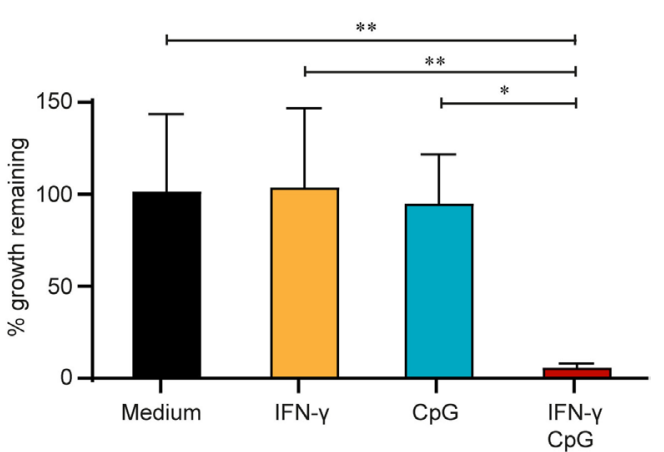

Medium $\square$ IFN-Y

TLR agonist

IFN- $y+$ TLR agonist 
FIGURE 2 | Continued

Synergy between IFN- $\gamma$ and several TLR agonists for M1 macrophage activation. (A-F) Mitomycin C-treated bone marrow derived macrophages (BMDMs) $\left(6 \times 10^{4}\right.$ cells/well) were stimulated for $24 \mathrm{~h}$ with several TLR agonists at various concentrations in the presence or absence of IFN- $\gamma$ (40 ng/ml) before addition of $3,000 \mathrm{LLC}$ tumor cells/well, resulting in a 20:1 macrophage to target cell ratio. lipopolysaccharide (LPS) (1 $\mu \mathrm{g} / \mathrm{ml})+\mathrm{IFN}-\gamma(40 \mathrm{ng} / \mathrm{ml})$ was used as a positive control for macrophage activation. Radiolabeled thymidine incorporation in growing cells is shown on the $y$-axis as mean cpm values of triplicates \pm SD. The first column on the left show proliferation of BMDMs alone. The following TLR agonists were tested at the indicated concentrations: (A) TLR1/2 agonist Pam3CSK4; (B) TLR2/6 agonist lipotechoic acid (LTA); (C) TLR3 agonist Poly(l:C); (D) TLR5 agonist Flagellin; (E) TLR7 agonist CL264; and (F) TLR9 agonist CpG. All experiments were performed three times and representative experiments are shown. (G,H) Statistical analysis of the pooled results from 5 (G) and $4 \mathbf{( H )}$ growth inhibition assays performed as described above with the indicated TLR agonists. $y$-axis show \% remaining growth calculated by dividing cpm $\mathrm{c}_{20: 1}$ by $_{\mathrm{c}} \mathrm{cpm}\llcorner\mathrm{c}$ alone and multiplying with 100. $p$-values from multiple comparison test using one-way ANOVA is displayed as follows: ${ }^{\star} p$-value $<0.05,{ }^{* \star} p$-value $<0.01,{ }^{* \star \star} p$-value $<0.001$.

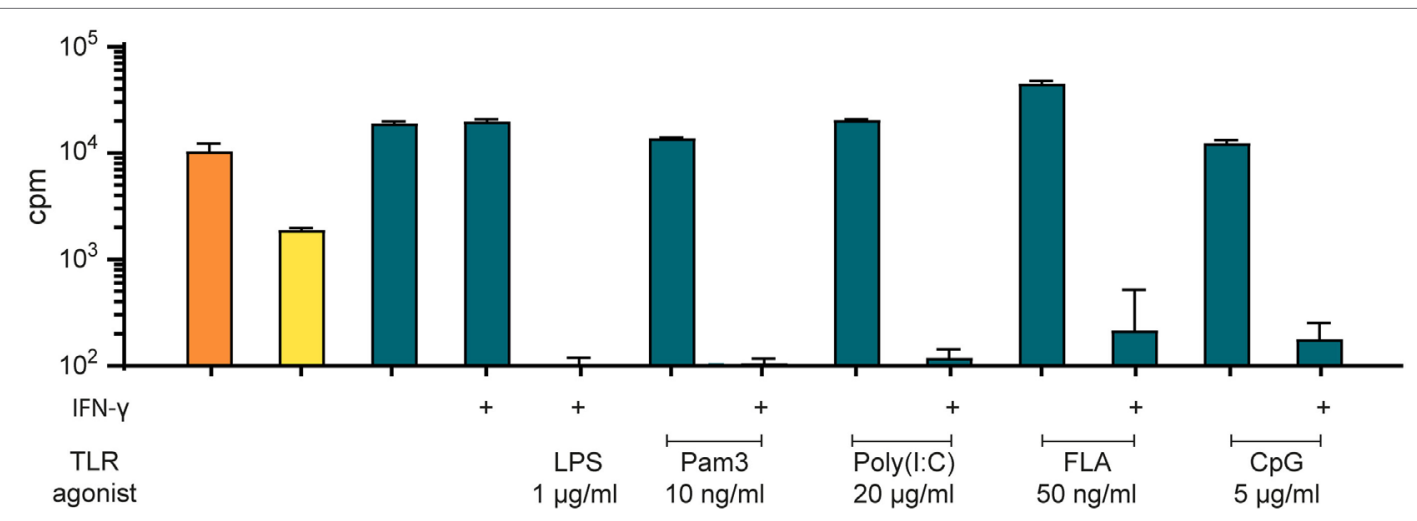

J774.A1 alone

J774.A1+MOPC315 (20:1 ratio)

MOPC315 alone

FIGURE 3 | The macrophage cell line J774.A1 inhibits tumor cell growth in a similar manner as bone marrow derived macrophages after two-signal activation. Growth inhibition assays. Mitomycin C-treated J774.A1 cells $\left(1 \times 10^{5}\right.$ cells/well) were stimulated with TLR agonists as indicated in the presence or absence of IFN- $\gamma$ ( $40 \mathrm{ng} / \mathrm{ml})$ for $18 \mathrm{~h}$ before addition of 5,000 MOPC315 tumor cells/well, resulting in a 20:1 effector to target cell ratio. Radiolabeled thymidine incorporation in growing cells is shown on the $y$-axis as mean cpm values of triplicates \pm SD. The first column on the left shows proliferation of target cells alone and the second column shows proliferation of effector cells alone. This experiment was performed three times and a representative experiment is shown.

used in the comparisons. The analysis revealed a statistically significant stronger growth inhibition when macrophages were activated by two signals (TLR agonist and IFN- $\gamma$ ) compared to one signal only (Figures 2G,H). Thus, induction of tumoricidal M1 macrophages can be achieved through stimulation of the TLRs $1 / 2,2 / 6,3,4,7$, or 9 when combined with IFN- $\gamma$. Stimulation of TLR 3 and 4 has some effect alone at high ligand concentrations. The only TLR agonist tested that did not activate BMDMs was flagellin (TLR5).

\section{A Macrophage Cell Line also Inhibits Tumor Cell Growth Following Stimulation with TLR Agonists and IFN- $\gamma$}

To investigate whether our findings were of a more general value rather than being specific to BMDMs, we tested an immortalized murine macrophage cell line, J774A.1, in the growth inhibition assay. Mitomycin C was used to block J774A.1 cell growth, before stimulation with TLR agonists alone or in combination with IFN- $\gamma$. When activated by LPS and IFN- $\gamma$, the macrophage cell line induced very strong growth inhibition of MOPC315 cells (Figure 3). These results were consistent with the growth inhibition mediated by BMDMs (Figure 2). We observed similar effect of co-stimulation with IFN- $\gamma$ and the agonists Pam3 and
CpG for the J774.A1 cell line and the BMDMs, whereas the effect of poly(I:C) combined with IFN- $\gamma$ was stronger for the cell line. IFN- $\gamma$ and flagellin also successfully stimulated J774A.1 to inhibit growth. Thus, murine macrophages, either primary cells or a cell line, could be activated toward a tumoricidal M1 phenotype by stimulation with IFN- $\gamma$ and a second signal. Several TLR agonists could provide this second signal.

\section{Tumor Cell Growth Inhibition by Activated Macrophages Is Mediated by NO}

Production of the cytotoxic free radical NO is considered a hallmark of M1-polarized pro-inflammatory macrophages (49). NO was shown to be crucial for macrophage-mediated defense against bacteria during normal immune responses (50) and has been reported to be important for the killing of tumor cells in vitro $(51,52)$. Due to the extremely short half-life of NO, we quantified it indirectly using the Griess assay. This assay is based on the Griess diazotization reaction of the NO metabolite nitrite $\left(\mathrm{NO}_{2}{ }^{-}\right)$which forms a colored azo compound that can be quantified with a spectrophotometer. We analyzed the supernatant of BMDMs during the growth inhibition assay just before tumor cells were added. Macrophage activation with LPS alone for $24 \mathrm{~h}$ resulted in a concentration-dependent NO production 
(Figure 4A). Stimulation with LPS in combination with IFN- $\gamma$ greatly potentiated the effect and yielded more than $10 \mu \mathrm{M}$ $\mathrm{NO}_{2}{ }^{-}$already at the lowest concentration of LPS that was tested $(0.1 \mathrm{ng} / \mathrm{ml}$ ) (Figure 4A). At 1,000 ng/ml of LPS, there was no clear additive effect of co-stimulation with IFN- $\gamma$, and the $\mathrm{NO}_{2}{ }^{-}$ production seemed to reach a maximum level around $15 \mu \mathrm{M}$. These results, where stimulation with IFN- $\gamma$ greatly improved the effect of LPS, are in accordance with previous studies on NO induction (53). These data also support our finding in the growth inhibition assay, showing that stimulation with two signals is required for optimal induction of M1 macrophage phenotype, defined either by tumoricidal activity or NO production.

To investigate the importance of NO in macrophage-mediated tumor cell growth inhibition, we used the iNOS-specific inhibitor SMT to block NO production (43). SMT completely blocked NO production by activated BMDMs when used at $10 \mathrm{mM}$ concentration, whereas $1 \mathrm{mM}$ only partly hindered $\mathrm{NO}$ production (Figure 4B). When tested in the growth inhibition assay, $1 \mathrm{mM}$
SMT was sufficient to abolish the growth inhibition induced both by LPS alone (Figure 4C) and by LPS in combination with IFN- $\gamma$ (Figure 4D). These data strongly suggest that macrophages mediate growth inhibition of tumor cells through a NO-dependent mechanism.

\section{Cell-free NO Is Cytotoxic at a High Concentration}

To test whether we could recreate the growth inhibitory effect of $\mathrm{NO}$ without the presence of macrophages, we used the chemical compound diethylenetriamine/NO adduct (DETA/NO), which functions as an $\mathrm{NO}$ donor and releases $\mathrm{NO}$ to the medium. We set up a modified growth inhibition assay where tumor cells were exposed to DETA/NO in the absence of macrophages (Figure 5A). DETA/NO was dissolved in cell culture medium and used immediately. Just before adding the DETA/NO solution to the MOPC315 target cells, the amount of NO released

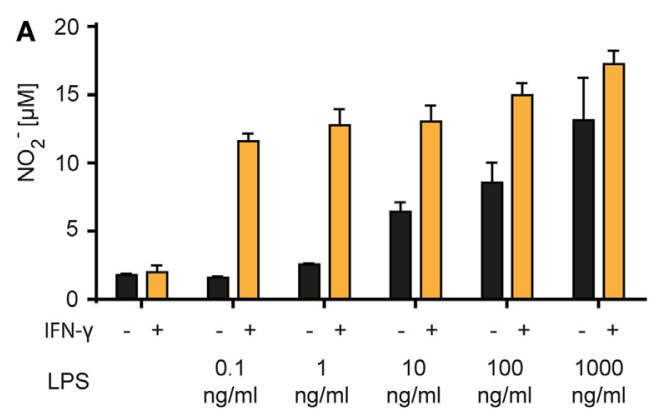

Medium $\square$ IFN-Y

C

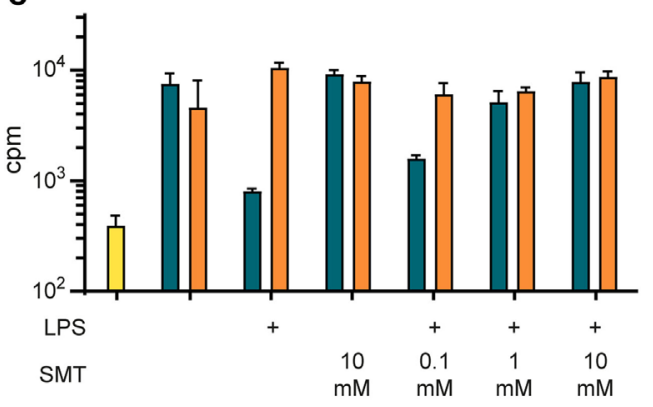

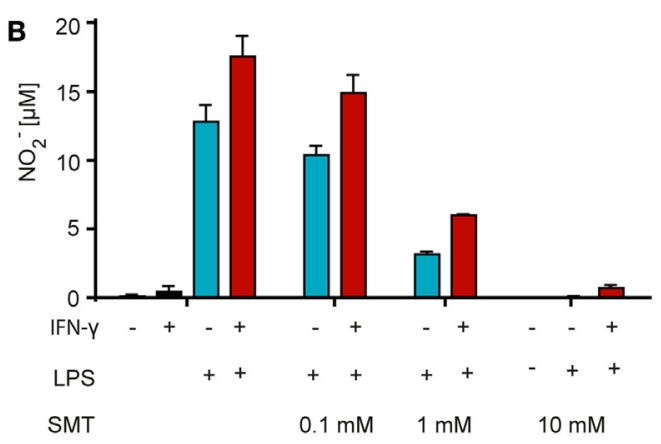

Medium LPS IFN-y + LPS

D

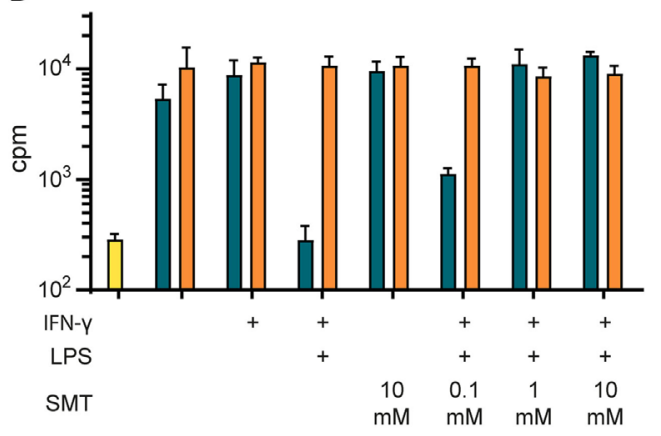

Macrophages alone $\square$ Macrophages+MOPC315 (12:1 ratio) $\square$ MOPC315 alone

FIGURE 4 | Tumor cell growth inhibition by activated macrophages is mediated by NO. (A) Bone marrow derived macrophages (BMDMs) $\left(6 \times 10^{4}\right.$ cells/well) were stimulated with different concentrations of lipopolysaccharide (LPS) alone or in combination with IFN- $\gamma$ (40 ng/ml) for 24 h. The Griess assay was used to measure $\mathrm{NO}$ in the supernatants indirectly as nitrite $\left(\mathrm{NO}_{2}^{-}\right)$. $\mathrm{NO}_{2}^{-}$levels $(\mu \mathrm{M})$ are presented as mean values of triplicates $\pm \mathrm{SD}$. (B) BMDMs $\left(6 \times 10^{4}\right.$ cells/well) were incubated with various concentrations of the inducible NO synthase inhibitor SMT (S-Methylisothiourea hemisulfate salt) and stimulated with LPS (1 $\mu \mathrm{g} / \mathrm{ml})$ alone or in combination with IFN- $\gamma(40 \mathrm{ng} / \mathrm{ml})$ for $24 \mathrm{~h} . \mathrm{NO}_{2}{ }^{-}$concentration $(\mu \mathrm{M})$ in the supernatants was measured using the Griess assay and presented as mean values of triplicates \pm SD. (C,D) Growth inhibition assay. Mitomycin C-treated BMDMs (6 $\times 10^{4}$ cells/well) were stimulated for $24 \mathrm{~h}$ with LPS alone (1 $\mu$ g/ml) (C) or with LPS $(1 \mu \mathrm{g} / \mathrm{ml})+\mathrm{IFN}-\gamma(40 \mathrm{ng} / \mathrm{ml})$ (D) and treated with various concentrations of SMT before addition of 5,000 MOPC315 tumor cells/well, resulting in a 12:1 macrophage to target cell ratio. Radiolabeled thymidine incorporation in growing cells is shown on the $y$-axis as mean cpm values of triplicates \pm SD. The first column on the left show proliferation of BMDMs alone. (A-D) All experiments were performed three times and representative experiments are shown. 


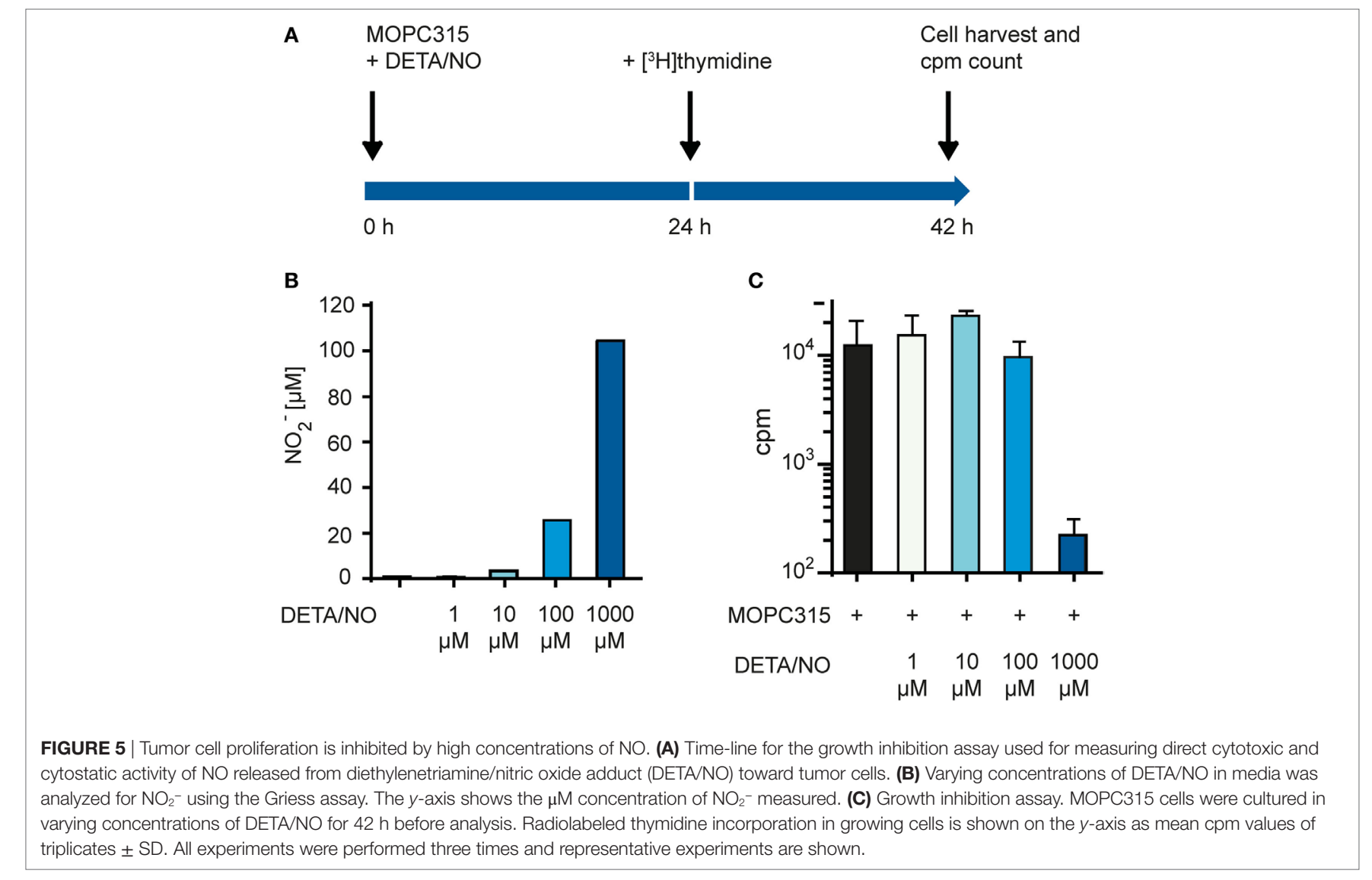

in the medium was quantified indirectly by measuring $\mathrm{NO}_{2}{ }^{-}$for each concentration of DETA/NO used (Figure 5B). MOPC315 growth was then quantified by measuring incorporation of radiolabeled thymidine as for the standard growth inhibition assay (Figure 5C). We found that inhibition of growth was obtained only at the highest tested DETA/NO concentration, i.e., $1 \mathrm{mM}$, which corresponds to a $\mathrm{NO}_{2}{ }^{-}$concentration of around $100 \mu \mathrm{M}$ (Figures 5A,B). These data confirm that our target tumor cells are sensitive to $\mathrm{NO}$ in a concentration-dependent way and are consistent with a key role of NO secretion for macrophage tumoricidal activity.

\section{TLR Agonists Mediate Tumor Cell Growth Inhibition via Production of NO}

To examine whether TLR agonists other than LPS also induce NO production, we stimulated BMDMs with TLR agonists both alone and in combination with IFN- $\gamma$ and measured the levels of $\mathrm{NO}_{2}{ }^{-}$in the supernatants (Figure 6A). For each TLR agonist, three concentrations were chosen and arbitrary defined as low, intermediate, and high. We found that all TLR agonists synergized with IFN- $\gamma$ for induction of NO production, as the $\mathrm{NO}_{2}{ }^{-}$levels were 2- to 10 -fold higher when BMDMs were activated with TLR agonists in combination with IFN- $\gamma$ compared with TLR agonists alone. IFN- $\gamma$ together with a low concentration of the TLR agonists still yielded more NO than single activation with TLR agonist at a 100-fold higher concentration (Figure 6A).
Thus, several TLR agonists can replace LPS as an activating signal for macrophage NO production.

Next, we wanted to verify that the inhibitor SMT could inhibit the NO production induced by any TLR agonist. Measurements by the Griess assay revealed that SMT reduced the levels of $\mathrm{NO}_{2}{ }^{-}$in the BMDM cultures stimulated with TLR agonists in combination with IFN- $\gamma$ (Figure 6B). Furthermore, we observed that the growth inhibition induced after co-stimulation with IFN- $\gamma$ and LPS or any other tested TLR agonist was abolished when the iNOS inhibitor was present (Figure 6C). Therefore, in vitro tumor cell growth inhibition after macrophage activation with any TLR agonist appears to depend on NO production. Table 2 shows a summary of the effect of all tested TLR agonists in combination with IFN- $\gamma$. There was a strong, but incomplete correlation between induction of NO production and tumor cell growth inhibition.

\section{IFN- $\gamma$ and TLR Agonists Synergize for Production of Pro-inflammatory and Th1-Polarizing Cytokines by BMDMs}

In the next set of experiments, we wanted to examine whether release of particular cytokines was affected by single versus two signal activation of macrophages. We measured the levels of the pro-inflammatory cytokines TNF- $\alpha$ and IL-12p40, the Th1polarizing cytokine IL-12p70, the anti-inflammatory cytokine IL-10, and the chemokine MIG/CXCL9 in the supernatant of 

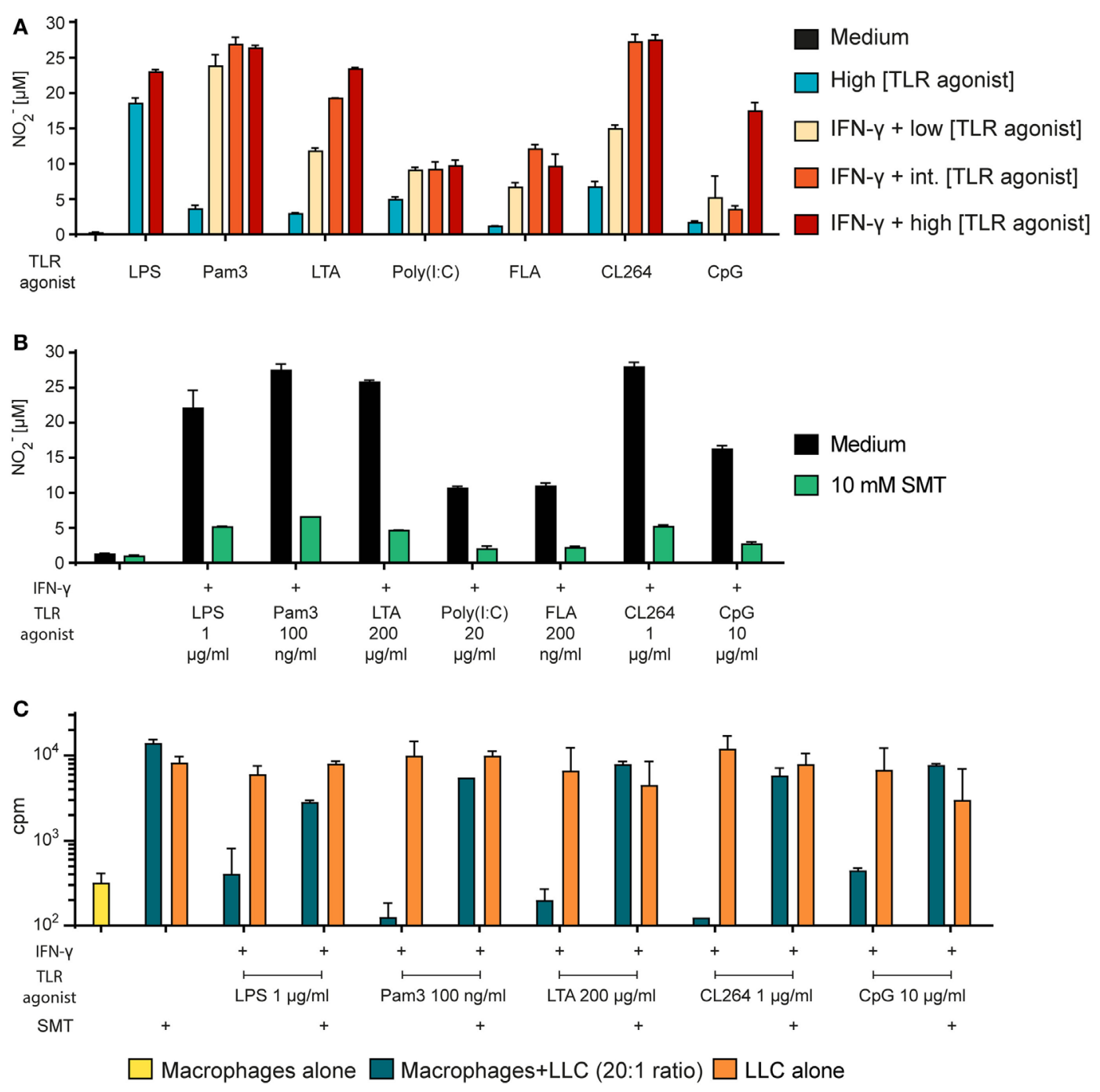

FIGURE 6 | Tumor cell growth inhibition by macrophages activated by any TLR agonist requires NO. (A) Bone marrow derived macrophages $(B M D M s)\left(6 \times 10^{4}\right.$ cells/well) were stimulated with TLR agonists alone or in combination with IFN- $\gamma(40 \mathrm{ng} / \mathrm{ml})$ as indicated for $24 \mathrm{~h} . \mathrm{NO}_{2}{ }^{-}$concentration $(\mu \mathrm{M})$ in the supernatants was measured using the Griess assay and presented as mean values of triplicates \pm SD. Each of the TLR agonists were tested at three concentrations (low/intermediate

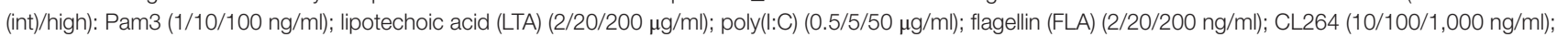
$\mathrm{CpG}(0.1 / 1 / 10 \mu \mathrm{g} / \mathrm{ml})$. (B) BMDMs $\left(6 \times 10^{4} \mathrm{cells} /\right.$ well) were incubated in the absence or presence of the inducible NO synthase inhibitor s-methylisothiourea hemisulfate salt (SMT) $(10 \mathrm{mM})$ and stimulated with TLR agonists as indicated and IFN- $\gamma(40 \mathrm{ng} / \mathrm{ml})$ for $24 \mathrm{~h} . \mathrm{NO}_{2}{ }^{-}$concentration $(\mu \mathrm{M})$ in the supernatants was measured using the Griess assay and presented as mean values of triplicates \pm SD. (C) Growth inhibition assay. Mitomycin C-treated BMDMs (6 $\times 10^{4}$ cells/well) were incubated in the absence or presence of SMT $(10 \mathrm{mM})$ and IFN- $\gamma(40 \mathrm{ng} / \mathrm{ml})$ in combination with TLR agonists as indicated for $24 \mathrm{~h}$ before addition of 3,000 LLC tumor cells/well, resulting in a 20:1 macrophage to target cell ratio. The growth of the tumor cells was quantified by measuring incorporation of radiolabeled thymidine and is shown on the $y$-axis as mean cpm values of triplicates \pm SD. The first column to the left show control wells with BMDMs alone (no tumor cells). (A-C) All experiments were performed three times and representative experiments are shown.

BMDMs stimulated for $24 \mathrm{~h}$ (Figure 7). There was a clear synergistic effect of IFN- $\gamma$ and most TLR agonists on the secretion of TNF- $\alpha$, IL-12p40, and IL-12p70. Activation with TLR agonists alone resulted in relatively low to medium cytokine levels which increased in response to LPS, Pam3, LTA, and CL264 when IFN- $\gamma$ was added (Figures 7A-C). IL-10 production was induced by TLR agonists alone with LPS giving the strongest response. Strikingly, IL-10 production induced by TLR triggering was reduced in the presence of IFN- $\gamma$ (Figure 7D). Exceptions were poly(I:C) and flagellin, which resulted in no or very low secretion of any cytokine both when used alone and in combination with IFN- $\gamma$. Untreated BMDMs produced no cytokines. BMDMs activated with IFN- $\gamma$ alone secreted no cytokines except for MIG/CXCL9 as expected for this IFN- $\gamma$-inducable chemokine. The chemokine MIG/CXCL9 was strongly induced by IFN- $\gamma$ alone and the levels were further increased upon combined activation with all TLR agonists, except LPS (Figure 7E). Thus, IFN- $\gamma$ and TLR agonists synergize to make macrophages produce high levels of proinflammatory and Th1-polarizing cytokines (TNF- $\alpha$, IL-12p40, and IL-12p70) and low levels of IL-10. 
TABLE 2 | Summary of TLR-mediated activation of macrophages in synergy with IFN- $\gamma$.

\begin{tabular}{|c|c|c|c|c|c|}
\hline \multicolumn{2}{|l|}{ Activation signal $^{a}$} & \multicolumn{2}{|c|}{$\begin{array}{c}\text { Bone marrow } \\
\text { derived } \\
\text { macrophages }\end{array}$} & \multicolumn{2}{|c|}{ J774.A1 } \\
\hline Agonist & TLR & $\mathrm{GIA}^{\mathrm{b}}$ & $\mathrm{NO}^{\mathrm{c}}$ & GIA & NO \\
\hline Lipopolysaccharide & TLR4 & ++ & ++ & ++ & ++ \\
\hline Pam3 & TLR1/2 & ++ & ++ & ++ & + \\
\hline Lipotechoic acid & TLR2/6 & ++ & ++ & ND & ND \\
\hline Poly(l:C) & TLR3 & + & + & ++ & + \\
\hline Flagellin & TLR5 & - & + & ++ & ++ \\
\hline CL264 & TLR7 & ++ & ++ & ND & ND \\
\hline CpG & TLR9 & ++ & ++ & ++ & + \\
\hline
\end{tabular}

${ }^{a}$ Given in combination with IFN- $\gamma$.

${ }^{b}$ Tumor cell growth inhibition assay (GIA): +, some inhibition; ++, strong inhibition; -, none; ND, not determined.

${ }^{c}$ Nitric oxide (NO) production. +, some; ++, strong; -, none; ND, not determined.

\section{DISCUSSION}

In this paper, we show that activation with two molecular signals from the microenvironment is required for efficient induction of M1 phenotype in murine macrophages as defined by tumoricidal activity, NO production, and secretion of proinflammatory and Th1-polarizing cytokines. We evaluated first two classical macrophage stimulators, namely LPS and IFN- $\gamma$. We found that IFN- $\gamma$ greatly potentiates the effect of LPS, resulting in strong tumoricidal activity at low LPS concentrations, whereas no tumoricidal activity was induced by IFN $-\gamma$ alone. A similar synergistic effect of LPS and IFN- $\gamma$ on induction of tumoricidal macrophages was shown previously by several investigators in the 1970s and 1980s $(16,18,19,21,22)$. However, the interpretation of many of these early studies is problematic due to variability in the source of macrophages and potentially impure or LPS-contaminated IFN- $\gamma$ (previously called MAF)
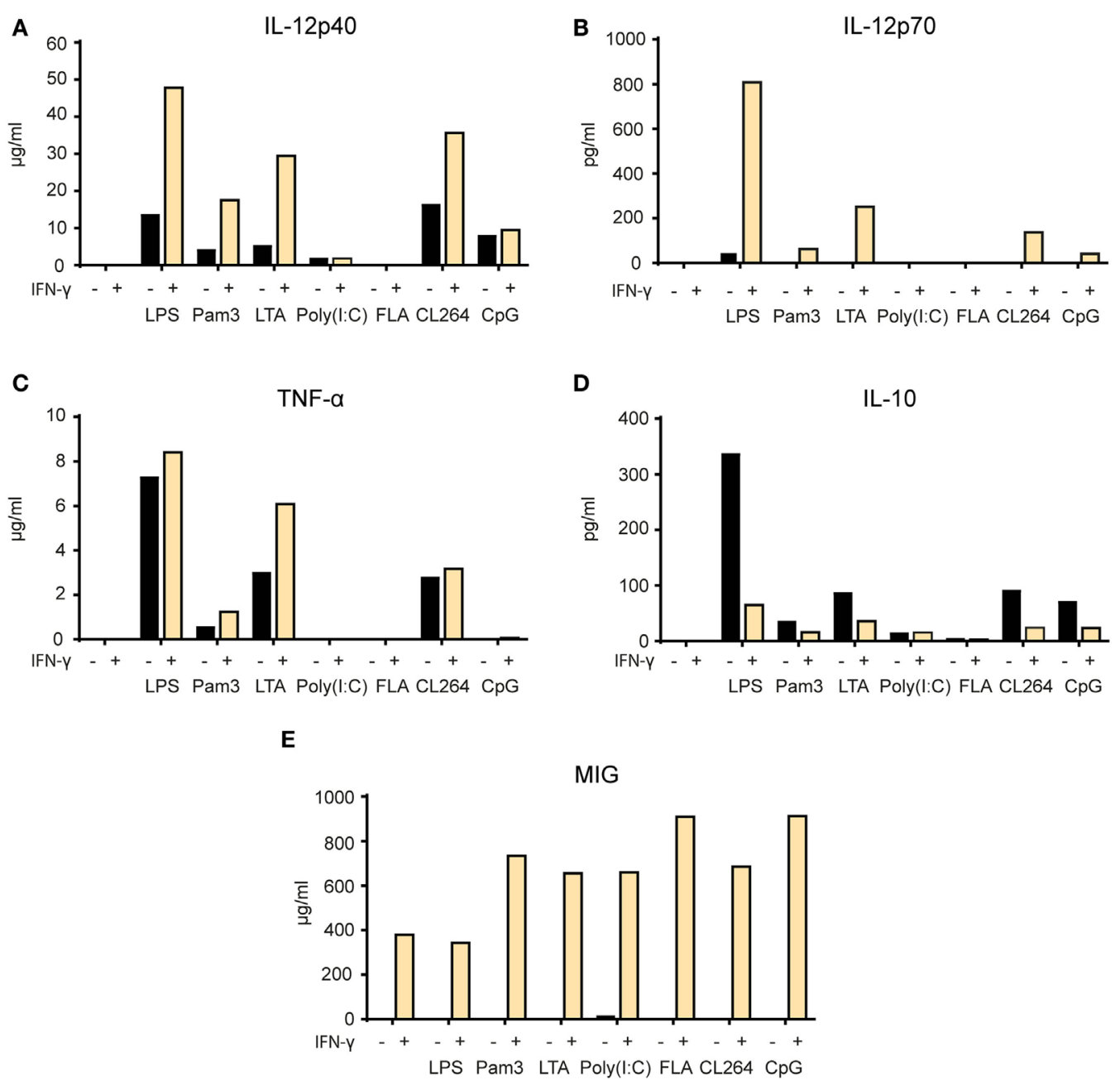

FIGURE 7 | Synergy between IFN- $\gamma$ and TLR agonists for induction of pro-inflammatory cytokine secretion by macrophages. (A-E) Mitomycin C-treated bone marrow derived macrophages $\left(2.4 \times 10^{4}\right.$ cells/well) were stimulated for $24 \mathrm{~h}$ with the following TLR agonists in the presence or absence of IFN- $\gamma(40 \mathrm{ng} / \mathrm{ml})$ :

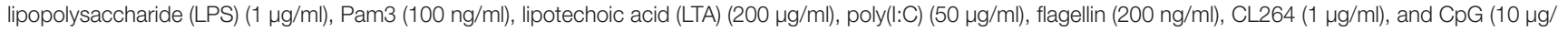
$\mathrm{ml})$. Cell supernatants were analyzed by Luminex technology and the cytokine content is shown on the $y$-axis as mean pg/ml or ng/ml values of duplicates. The following cytokines were measured: (A) IL-12p40, (B) IL-12p70, (C) TNF- $\alpha$, (D) IL-10, and (E) monokine-induced by IFN- $\gamma$ (MIG). All experiments were performed three times and representative experiments are shown. 
preparations. Peritoneal macrophages were used in most of the studies, and often peptone or thioglycollate was injected into the peritoneum to increase the yield of macrophages. These compounds may themselves give an inflammatory stimulus to the macrophages (54). Moreover, peritoneal macrophages may be contaminated by other cell types (55), and this is not accounted for in all studies. The literature also contains reports on induction of tumoricidal M1 macrophages by single activation with IFN- $\gamma$ or LPS $(56,57)$, and most recent reviews make no distinction between the macrophage phenotypes resulting from activation with IFN- $\gamma$, LPS, or both. Due to the potential of M1 macrophages for immunotherapy for cancer, a clarification of which signals are required for an optimal induction of these cells was needed. In pilot studies, we used peritoneal macrophages, but considerable variability between experiments was observed (data not shown). Therefore, we decided to use BMDM generated by standard protocols as source of normal mouse macrophages. Using BMDMs as effector cells, we could clearly show that IFN- $\gamma$ alone is ineffective at activating macrophages to a tumoricidal M1 phenotype. LPS had some effect alone, but only when it was used in high concentrations, indicating that M1 activation by LPS alone is sub-optimal. When macrophages were activated with IFN- $\gamma$ in combination with LPS, a potent tumoricidal phenotype was obtained even with the use of very low LPS concentrations. Thus, our data confirm earlier in vitro studies with LPS and IFN- $\gamma$ that revealed that two signals are required for inducing a tumoricidal M1 macrophage phenotype. This is also in line with our previous findings from an in vivo model of myeloma, where IFN- $\gamma$ was required, but not sufficient to explain the cytotoxic effect of TAMs, indicating the involvement of another signal $(7,11)$.

Based on our findings of the synergistic effect of IFN- $\gamma$ and the TLR4 agonist LPS, we wanted to investigate whether stimulation with LPS could be replaced by triggering any other TLR. Some TLR agonists have previously been reported to be able to induce tumoricidal M1 macrophages, but the TLR ligands were mostly used in combination with other agents such as TGF- $\beta$ inhibitors or CD40 agonists rather than IFN- $\gamma$ (see Table 1). Synergistic effects of several TLR agonists and IFN- $\gamma$ on macrophage expression of cytokines and NO production has been described $(58,59)$, but to the best of our knowledge the only TLR ligands that have been shown to synergize with IFN- $\gamma$ for induction of tumoricidal functions of macrophages are LPS and poly(I:C) (60). We therefore set up a panel of agonists covering most of the well-described TLRs in mice. We found that all TLR agonists synergized with IFN- $\gamma$ to induce a tumoricidal M1 macrophage phenotype. Flagellin, a TLR5 agonist, combined with IFN- $\gamma$ did not induce any tumor cell growth inhibition by BMDMs, but it activated the macrophage cell line J774.A1. This could be explained by various factors such as lower TLR5 receptor expression by BMDMs compared to J774.A1. Importantly, all TLR agonists, with the exception of LPS and poly(I:C), had no effect when used alone, but induced potent macrophage-mediated tumor cell growth inhibition when combined with IFN- $\gamma$. This may explain the lack of reports on induction of tumoricidal M1 macrophages by other TLR agonists, as previous studies have not included
IFN- $\gamma$ in the activation protocol (Table 1). Several recent studies revealed the therapeutic potential of activating TAMs toward an antitumor M1 phenotype, resulting in macrophagemediated tumor immune surveillance with tumor regression in vivo (8-10). These proof-of-principle reports support the potential application of our findings in the development of novel macrophage-targeted cancer therapies by combining IFN- $\gamma$ with TLR agonists.

Our experiments demonstrated that the presence of NO was necessary for cancer cell growth inhibition by macrophages, which is consistent with recent studies reporting the importance of NO in macrophage-mediated antitumor effects $(61,62)$. NO was found to be the main mediator of the tumoricidal effect of activated macrophages in a number of studies from the $1980 \mathrm{~s}$ $(51,52,63)$, but some reports also indicate the existence of iNOS-independent mechanisms (64). Inhibition of iNOS in activated macrophages resulted in a concentration-dependent abrogation of both NO production and tumor cell growth inhibition. Production of NO by BMDMs correlated with tumor cell growth inhibition, but could not be used as a predictive surrogate marker for tumoricidal activity (Table 2). This finding has consequences for the interpretation of previous studies as well as the planning of future studies aimed at inducing tumoricidal M1 macrophages. M1 macrophages were originally defined as having a killer phenotype with a characteristic shift in L-arginine metabolism into NO production, as opposed to healing M2 macrophages which use L-arginine to generate L-ornithine and urea $(3,65)$. Consequently, induction of iNOS, the enzyme responsible for production of NO by activated macrophages, has been established as a hallmark of tumoricidal M1 macrophages (66). We would argue that the widespread use of iNOS-expression or NO production by macrophages as a surrogate marker of tumoricidal M1 macrophages should be replaced or accompanied by functional assays that directly measure the tumoricidal activity of macrophages.

We observed a synergistic effect of IFN- $\gamma$ and TLR agonists on the induction of the pro-inflammatory cytokines TNF- $\alpha$ and IL-12p40, and the Th1-polarizing cytokine IL-12p70 (also called IL-12p75), while the angiostatic chemokine MIG (or CXCL9) was induced by IFN- $\gamma$ alone. We have previously reported in mouse models for myeloma and lymphoma that the secretion of these cytokines was associated with successful immunity against cancer (11). Furthermore, production of TNF- $\alpha$ and IL-12 cytokines plays important roles in macrophage-mediated immune responses to pathogens and cancer (67), and the observation that TLR agonists and IFN- $\gamma$ synergize for this function fits well with previous studies $(68,69)$. Interestingly, the results for the anti-inflammatory cytokine IL-10 were different, as IFN- $\gamma$ reduced the induction of IL-10 seen by TLR activation alone. The ability of IFN- $\gamma$ to inhibit IL-10 production has been previously described and suggested as a potential mechanism underlying the synergistic effect of IFN- $\gamma$ on TLR-mediated macrophage activation (70). IL-10 is induced at a low level upon TLR activation and mediates a negative feedback loop involving induction of STAT3 $(71,72)$. IFN- $\gamma$ was shown to inhibit IL-10 production by increasing the activity glycogen synthase kinase $3 \beta$ (GSK-3 $\beta$ ), a negative regulator of AP-1 and CREB signaling 
(70). GSK-3 $\beta$ mediated the synergistic activity of IFN- $\gamma$ on increasing NF- $\kappa \mathrm{B}$ activity, NO production and IL- 6 secretion in TLR-activated macrophages $(73,74)$. So far, GSK-3 $\beta$ has been shown to be a key regulator of TLR2 and TLR4 signaling, and potentially also TLR3 (75). However, more studies are required to clarify the role of GSK-3 $\beta$ in the synergistic effect of IFN- $\gamma$ and other TLRs, as well as whether this regulatory pathway can explain why a combination of IFN- $\gamma$ and TLR agonists are required for optimal induction of tumoricidal M1 activity in macrophages.

Our data confirm previous findings showing that LPS and poly(I:C) may induce some macrophage-mediated tumor cell growth inhibition in the absence of IFN- $\gamma$ (17). At first glance, this contradicts our conclusion that M1 macrophage polarization requires two signals. However, it has been reported that LPS and poly(I:C) might in fact act by combining TLR signaling with autocrine type I interferon signaling (76). Torres and Johnson demonstrated that both LPS and poly(I:C) induced secretion of IFN $-\alpha / \beta$ and that the tumoricidal activity induced by LPS or poly(I:C) could be abrogated by neutralizing antibodies against IFN- $\alpha / \beta$, but not against IFN- $\gamma(76)$. Adding IFN- $\gamma$ to poly(I:C)-activated macrophages after IFN- $\alpha / \beta$-blocking could rescue the tumoricidal activity. Furthermore, Pace et al. observed that both IFN- $\alpha$ and $\beta$ could synergize with LPS or heat killed Listeria monocytogenes for the induction of tumoricidal activity, however less potently than IFN- $\gamma$ (77). After the discovery of the receptors that recognize LPS and poly(I:C), TLR4 and TLR3 respectively, and the signaling pathways involved, it has become clear that these two TLRs share the ability to signal via a TRIF-dependent pathway, resulting in activation of IRF3 and induction of type I interferons $(78,79)$. The other main signaling pathway used by TLRs depends on MyD88 and results in activation of NFKB rather than IRF3 (80). TLR4 is the only TLR that is able to activate both pathways, and this has been suggested to explain the powerful effect of LPS on macrophage activation. Synergistic effects on cytokine production and T cell stimulation from combined activation of macrophages with MyD88dependent and TRIF-dependent TLR agonists have previously been described (81), and may provide a novel way of inducing tumoricidal M1 macrophages. Thus, the two-signal model for induction of tumoricidal M1 macrophages might be extended to encompass interferon- $\alpha / \beta / \gamma$-signaling and signaling through a large range of TLRs. Such insight on 2-signal requirement should be valuable for the development of future macrophage-targeted cancer therapies.

Our data suggest a general mechanism of TLR and IFN- $\gamma$ mediated signaling that synergizes for induction of antitumor M1 macrophage phenotype. The striking functional similarities between different TLR agonists suggest that differential TLR expression between mouse and human macrophages might not represent a major problem for therapy development, since multiple TLR agonists may potentially be used. It has been shown that monocyte-derived human macrophages could inhibit tumor cell growth in vitro upon combined activation with LPS and IFN- $\gamma(44)$, suggesting that the rules for induction of M1 macrophage phenotype may be conserved across these two species. Another important issue that will need clarification is whether TLR activation in combination with IFN- $\gamma$ will be sufficient to induce M1 phenotype in TAMs which are considered to be polarized differently in M2 or M2-like modus. Such repolarization has been reported using several activation protocols, including miRNA (82). Interestingly, a TLR7 agonist was shown to be effective at reversing the pro-tumor phenotype of murine TAMs in vitro, but only in combination with TGF- $\beta$ blockade (35). We propose that exploiting the synergistic effect of combined macrophage activation with IFN- $\gamma$ and TLR agonist may have a great potential for development of novel tumor immunotherapies.

\section{ETHICS STATEMENT}

The study was approved by the Norwegian National Committee for Animal Experiments. All experiments were performed in accordance with the institutional guidelines and regulations, including EU directive 2010/63/EU.

\section{AUTHOR CONTRIBUTIONS}

EM performed most experimental work, analyzed results, and wrote the manuscript. PC performed experimental work, analyzed results, and contributed to writing the final version of the manuscript. SH performed experimental work on the cell line and analyzed results. AL performed early, preliminary experimental work. KB provided help with cell culture work and materials. MS provided BMDM material and protocol and contributed to writing the final version of the manuscript. $\varnothing \varnothing$ provided supervision and experimental help, discussed the results, and contributed to writing the final version of the manuscript. AC designed, supervised, and evaluated the experiments and contributed to writing the manuscript. All authors read and approved the final version of the manuscript.

\section{ACKNOWLEDGMENTS}

The authors would like to thank Kathrine Hagelsteen for invaluable support for cell culture work, Marte Fauskanger for help in establishing the growth inhibition protocol, Kari Tvete Inngjerdingen for help in establishing the NO assay, and Julie Katrine Lindstad for training in the Luminex Technology.

\section{FUNDING}

This work was supported by grants from the Research Council of Norway, the South-Eastern Norway Regional Health Authority, Henrik Homans Minde fund, Ella and Kristian Nyerrøds fund, and S. G. Sønneland Foundation fund. 


\section{REFERENCES}

1. Biswas SK, Mantovani A. Macrophage plasticity and interaction with lymphocyte subsets: cancer as a paradigm. Nat Immunol (2010) 11(10):889-96. doi:10.1038/ni.1937

2. Mantovani A, Marchesi F, Malesci A, Laghi L, Allavena P. Tumour-associated macrophages as treatment targets in oncology. Nat Rev Clin Oncol (2017) 14(7):399-416. doi:10.1038/nrclinonc.2016.217

3. Mills CD, Kincaid K, Alt JM, Heilman MJ, Hill AM. M-1/M-2 macrophages and the Th1/Th2 paradigm. J Immunol (2000) 164(12):6166-73. doi:10.4049/ jimmunol.164.12.6166

4. Mantovani A, Sozzani S, Locati M, Allavena P, Sica A. Macrophage polarization: tumor-associated macrophages as a paradigm for polarized M2 mononuclear phagocytes. Trends Immunol (2002) 23(11):549-55. doi:10.1016/ S1471-4906(02)02302-5

5. Mantovani A, Sica A. Macrophages, innate immunity and cancer: balance, tolerance, and diversity. Curr Opin Immunol (2010) 22(2):231-7. doi:10.1016/ j.coi.2010.01.009

6. Pyonteck SM, Akkari L, Schuhmacher AJ, Bowman RL, Sevenich L, Quail DF, et al. CSF-1R inhibition alters macrophage polarization and blocks glioma progression. Nat Med (2013) 19(10):1264-72. doi:10.1038/nm.3337

7. Corthay A, Skovseth DK, Lundin KU, Røsjø E, Omholt H, Hofgaard PO, et al. Primary antitumor immune response mediated by CD4+ T cells. Immunity (2005) 22(3):371-83. doi:10.1016/j.immuni.2005.02.003

8. Beatty GL, Chiorean EG, Fishman MP, Saboury B, Teitelbaum UR, Sun W, et al. CD40 agonists alter tumor stroma and show efficacy against pancreatic carcinoma in mice and humans. Science (2011) 331(6024):1612-6. doi:10.1126/science.1198443

9. Kaneda MM, Messer KS, Ralainirina N, Li H, Leem CJ, Gorjestani S, et al. PI3Kgamma is a molecular switch that controls immune suppression. Nature (2016) 539(7629):437-42. doi:10.1038/nature19834

10. Guerriero JL, Sotayo A, Ponichtera HE, Castrillon JA, Pourzia AL, Schad S, et al. Class IIa HDAC inhibition reduces breast tumours and metastases through anti-tumour macrophages. Nature (2017) 543(7645):428-32. doi:10.1038/ nature 21409

11. Haabeth OA, Lorvik KB, Hammarström C, Donaldson IM, Haraldsen G, Bogen $\mathrm{B}$, et al. Inflammation driven by tumour-specific Th1 cells protects against B-cell cancer. Nat Commun (2011) 2:240. doi:10.1038/ncomms1239

12. Porta C, Riboldi E, Ippolito A, Sica A. Molecular and epigenetic basis of macrophage polarized activation. Semin Immunol (2015) 27(4):237-48. doi:10.1016/j.smim.2015.10.003

13. Evans R, Alexander P. Cooperation of immune lymphoid cells with macrophages in tumour immunity. Nature (1970) 228(5272):620-2. doi:10.1038/ 228620a0

14. Evans R, Alexander P. Mechanism of immunologically specific killing of tumour cells by macrophages. Nature (1972) 236(5343):168-70. doi:10.1038/ $236168 \mathrm{a} 0$

15. Schreiber RD, Pace JL, Russell SW, Altman A, Katz DH. Macrophage-activating factor produced by a $\mathrm{T}$ cell hybridoma: physiochemical and biosynthetic resemblance to gamma-interferon. J Immunol (1983) 131(2):826-32.

16. Pace JL, Russell SW, Schreiber RD, Altman A, Katz DH. Macrophage activation: priming activity from a T-cell hybridoma is attributable to interferon-gamma. Proc Natl Acad Sci U S A (1983) 80(12):3782-6. doi:10.1073/pnas.80.12.3782

17. Alexander P, Evans R. Endotoxin and double stranded RNA render macrophages cytotoxic. Nat New Biol (1971) 232(29):76-8. doi:10.1038/ newbio232076a0

18. Hibbs JB Jr, Taintor RR, Chapman HA Jr, Weinberg JB. Macrophage tumor killing: influence of the local environment. Science (1977) 197(4300):279-82. doi:10.1126/science.327547

19. Ruco LP, Meltzer MS. Macrophage activation for tumor cytotoxicity: tumoricidal activity by macrophages from $\mathrm{C} 3 \mathrm{H} / \mathrm{HeJ}$ mice requires at least two activation stimuli. Cell Immunol (1978) 41(1):35-51. doi:10.1016/S00088749(78)80026-4

20. Weinberg JB, Chapman HA Jr, Hibbs JB Jr. Characterization of the effects of endotoxin on macrophage tumor cell killing. J Immunol (1978) 121(1):72-80.

21. Meltzer MS. Macrophage activation for tumor cytotoxicity: characterization of priming and trigger signals during lymphokine activation. J Immunol (1981) 127(1):179-83.
22. Pace JL, Russell SW. Activation of mouse macrophages for tumor cell killing. I. Quantitative analysis of interactions between lymphokine and lipopolysaccharide. J Immunol (1981) 126(5):1863-7.

23. Mantovani A, Biswas SK, Galdiero MR, Sica A, Locati M. Macrophage plasticity and polarization in tissue repair and remodelling. J Pathol (2013) 229(2):176-85. doi:10.1002/path.4133

24. Martinez FO, Gordon S. The M1 and M2 paradigm of macrophage activation: time for reassessment. F1000Prime Rep (2014) 6:13. doi:10.12703/P6-13

25. Mosser DM, Edwards JP. Exploring the full spectrum of macrophage activation. Nat Rev Immunol (2008) 8(12):958-69. doi:10.1038/nri2448

26. Murray PJ, Allen JE, Biswas SK, Fisher EA, Gilroy DW, Goerdt S, et al. Macrophage activation and polarization: nomenclature and experimental guidelines. Immunity (2014) 41(1):14-20. doi:10.1016/j.immuni.2014.06.008

27. Barros MH, Hauck F, Dreyer JH, Kempkes B, Niedobitek G. Macrophage polarisation: an immunohistochemical approach for identifying M1 and M2 macrophages. PLoS One (2013) 8(11):e80908. doi:10.1371/journal.pone. 0080908

28. Xue J, Schmidt SV, Sander J, Draffehn A, Krebs W, Quester I, et al. Transcriptome-based network analysis reveals a spectrum model of human macrophage activation. Immunity (2014) 40(2):274-88. doi:10.1016/j.immuni. 2014.01.006

29. Lundin JI, Checkoway H. Endotoxin and cancer. Environ Health Perspect (2009) 117(9):1344-50. doi:10.1289/ehp.0800439

30. Iribarren K, Bloy N, Buqué A, Cremer I, Eggermont A, Fridman WH, et al. Trial watch: immunostimulation with toll-like receptor agonists in cancer therapy. Oncoimmunology (2016) 5(3):e1088631. doi:10.1080/21624 02X.2015.1088631

31. Mäkelä SM, Strengell M, Pietilä TE, Osterlund P, Julkunen I. Multiple signaling pathways contribute to synergistic TLR ligand-dependent cytokine gene expression in human monocyte-derived macrophages and dendritic cells. J Leukoc Biol (2009) 85(4):664-72. doi:10.1189/jlb.0808503

32. Lee M, Park CS, Lee YR, Im SA, Song S, Lee CK. Resiquimod, a TLR7/8 agonist, promotes differentiation of myeloid-derived suppressor cells into macrophages and dendritic cells. Arch Pharm Res (2014) 37(9):1234-40. doi:10.1007/s12272-014-0379-4

33. Shime H, Matsumoto M, Oshiumi H, Tanaka S, Nakane A, Iwakura Y, et al. Toll-like receptor 3 signaling converts tumorsupporting myeloid cells to tumoricidal effectors. Proc Natl Acad Sci U S A (2012) 109(6):2066-71. doi:10.1073/pnas.1113099109

34. Keller R, Fischer W, Keist R, Bassetti S. Macrophage response to bacteria: induction of marked secretory and cellular activities by lipoteichoic acids. Infect Immun (1992) 60(9):3664-72.

35. Peng J, Tsang JY, Li D, Niu N, Ho DH, Lau KF, et al. Inhibition of TGF-beta signaling in combination with TLR7 ligation re-programs a tumoricidal phenotype in tumor-associated macrophages. Cancer Lett (2013) 331(2): 239-49. doi:10.1016/j.canlet.2013.01.001

36. Wang J, Shirota Y, Bayik D, Shirota H, Tross D, Gulley JL, et al. Effect of TLR agonists on the differentiation and function of human monocytic myeloidderived suppressor cells. J Immunol (2015) 194(9):4215-21. doi:10.4049/ jimmunol.1402004

37. Shirota Y, Shirota H, Klinman DM. Intratumoral injection of CpG oligonucleotides induces the differentiation and reduces the immunosuppressive activity of myeloid-derived suppressor cells. J Immunol (2012) 188(4):1592-9. doi:10.4049/jimmunol.1101304

38. Gehring U, Mohit B, Tomkins GM. Glucocorticoid action on hybrid clones derived from cultured myeloma and lymphoma cell lines. Proc Natl Acad Sci US A (1972) 69(11):3124-7. doi:10.1073/pnas.69.11.3124

39. Bertram JS, Janik P. Establishment of a cloned line of Lewis Lung Carcinoma cells adapted to cell culture. Cancer Lett (1980) 11(1):63-73. doi:10.1016/ 0304-3835(80)90130-5

40. Sanford KK, Earle WR, Likely GD. The growth in vitro of single isolated tissue cells. J Natl Cancer Inst (1948) 9(3):229-46.

41. Ralph P, Nakoinz I. Antibody-dependent killing of erythrocyte and tumor targets by macrophage-related cell lines: enhancement by PPD and LPS. J Immunol (1977) 119(3):950-4.

42. Weischenfeldt J, Porse B. Bone marrow-derived macrophages (BMM): isolation and applications. CSH Protoc (2008) 3(12):1-6. doi:10.1101/pdb. prot5080 
43. Southan GJ, Szabo C, Thiemermann C. Isothioureas: potent inhibitors of nitric oxide synthases with variable isoform selectivity. Br J Pharmacol (1995) 114(2):510-6. doi:10.1111/j.1476-5381.1995.tb13256.x

44. Cameron DJ, Churchill WH. Cytotoxicity of human macrophages for tumor cells: enhancement by bacterial lipopolysaccharides (LPS). J Immunol (1980) 124(2):708-12.

45. Buhtoiarov IN, Lum HD, Berke G, Sondel PM, Rakhmilevich AL. Synergistic activation of macrophages via CD40 and TLR9 results in T cell independent antitumor effects. J Immunol (2006) 176(1):309-18. doi:10.4049/ jimmunol.176.1.309

46. Luo Y, Yamada H, Evanoff DP, Chen X. Role of Th1-stimulating cytokines in bacillus Calmette-Guérin (BCG)-induced macrophage cytotoxicity against mouse bladder cancer MBT-2 cells. Clin Exp Immunol (2006) 146(1):181-8. doi:10.1111/j.1365-2249.2006.03191.x

47. Buhtoiarov IN, Sondel PM, Eickhoff JC, Rakhmilevich AL. Macrophages are essential for antitumour effects against weakly immunogenic murine tumours induced by class B CpG-oligodeoxynucleotides. Immunology (2007) 120(3):412-23. doi:10.1111/j.1365-2567.2006.02517.x

48. Rakhmilevich AL, Baldeshwiler MJ, Van De Voort TJ, Felder MA, Yang RK, Kalogriopoulos NA, et al. Tumor-associated myeloid cells can be activated in vitro and in vivo to mediate antitumor effects. Cancer Immunol Immunother (2012) 61(10):1683-97. doi:10.1007/s00262-012-1236-2

49. Rath M, Müller I, Kropf P, Closs EI, Munder M. Metabolism via arginase or nitric oxide synthase: two competing arginine pathways in macrophages. Front Immunol (2014) 5:532. doi:10.3389/fimmu.2014.00532

50. Adams LB, Hibbs JB Jr, Taintor RR, Krahenbuhl JL. Microbiostatic effect of murine-activated macrophages for Toxoplasma gondii. Role for synthesis of inorganic nitrogen oxides from L-arginine. J Immunol (1990) 144(7):2725-9.

51. Hibbs JB Jr, Taintor RR, Vavrin Z, Rachlin EM. Nitric oxide: a cytotoxic activated macrophage effector molecule. Biochem Biophys Res Commun (1988) 157(1):87-94. doi:10.1016/S0006-291X(88)80015-9

52. Stuehr DJ, Nathan CF. Nitric oxide. A macrophage product responsible for cytostasis and respiratory inhibition in tumor target cells. J Exp Med (1989) 169(5):1543-55. doi:10.1084/jem.169.5.1543

53. Noda T, Amano F. Differences in nitric oxide synthase activity in a macrophage-like cell line, RAW264.7 cells, treated with lipopolysaccharide (LPS) in the presence or absence of interferon-gamma (IFN-gamma): possible heterogeneity of iNOS activity. J Biochem (1997) 121(1):38-46. doi:10.1093/ oxfordjournals.jbchem.a021566

54. Lam D, Harris D, Qin Z. Inflammatory mediator profiling reveals immune properties of chemotactic gradients and macrophage mediator production inhibition during thioglycollate elicited peritoneal inflammation. Mediators Inflamm (2013) 2013:931562. doi:10.1155/2013/931562

55. Misharin AV, Saber R, Perlman H. Eosinophil contamination of thioglycollate-elicited peritoneal macrophage cultures skews the functional readouts of in vitro assays. J Leukoc Biol (2012) 92(2):325-31. doi:10.1189/ jlb.1111560

56. Dileepan KN, Page JC, Li Y, Stechschulte DJ. Direct activation of murine peritoneal macrophages for nitric oxide production and tumor cell killing by interferon-gamma. J Interferon Cytokine Res (1995) 15(5):387-94. doi:10.1089/ jir.1995.15.387

57. Lavnikova N, Drapier JC, Laskin DL. A single exogenous stimulus activates resident rat macrophages for nitric oxide production and tumor cytotoxicity. J Leukoc Biol (1993) 54(4):322-8.

58. Paulnock DM, Demick KP, Coller SP. Analysis of interferon-gammadependent and -independent pathways of macrophage activation. JLeukoc Biol (2000) 67(5):677-82.

59. Kang SS, Ryu YH, Baik JE, Yun CH, Lee K, Chung DK, et al. Lipoteichoic acid from Lactobacillus plantarum induces nitric oxide production in the presence of interferon-gamma in murine macrophages. Mol Immunol (2011) 48(15-16):2170-7. doi:10.1016/j.molimm.2011.07.009

60. Herriott MJ, Leu RW. Activation of mouse macrophages for migration inhibition and for tumor cytotoxicity is mediated by interferon-gamma priming and triggering by various agents. J Interferon Res (1987) 7(2):165-71. doi:10.1089/jir.1987.7.165

61. Buhtoiarov IN, Sondel PM, Wigginton JM, Buhtoiarova TN, Yanke EM, Mahvi DA, et al. Anti-tumour synergy of cytotoxic chemotherapy and
anti-CD40 plus CpG-ODN immunotherapy through repolarization of tumour-associated macrophages. Immunology (2011) 132(2):226-39. doi:10.1111/j.1365-2567.2010.03357.x

62. Lizotte PH, Baird JR, Stevens CA, Lauer P, Green WR, Brockstedt DG, et al. Attenuated Listeria monocytogenes reprograms M2-polarized tumor-associated macrophages in ovarian cancer leading to iNOS-mediated tumor cell lysis. Oncoimmunology (2014) 3:e28926. doi:10.4161/onci.28926

63. Hibbs JB Jr, Taintor RR, Vavrin Z. Macrophage cytotoxicity: role for $\mathrm{L}$-arginine deiminase and imino nitrogen oxidation to nitrite. Science (1987) 235(4787):473-6. doi:10.1126/science.2432665

64. Cui S, Reichner JS, Mateo RB, Albina JE. Activated murine macrophages induce apoptosis in tumor cells through nitric oxide-dependent or independent mechanisms. Cancer Res (1994) 54(9):2462-7.

65. Mills CD, Shearer J, Evans R, Caldwell MD. Macrophage arginine metabolism and the inhibition or stimulation of cancer. J Immunol (1992) 149(8):2709-14

66. Lowenstein CJ, Padalko E. iNOS (NOS2) at a glance. J Cell Sci (2004) 117(Pt 14):2865-7. doi:10.1242/jcs.01166

67. Haabeth OA, Bogen B, Corthay A. A model for cancer-suppressive inflammation. Oncoimmunology (2012) 1(7):1146-55. doi:10.4161/onci.21542

68. Lee JY, Sullivan KE. Gamma interferon and lipopolysaccharide interact at the level of transcription to induce tumor necrosis factor alpha expression. Infect Immun (2001) 69(5):2847-52. doi:10.1128/IAI.69.5.2847-2852.2001

69. Abdi K, Singh N, Matzinger P. T-cell control of IL-12p75 production. Scand J Immunol (2006) 64(2):83-92. doi:10.1111/j.1365-3083.2006.01767.x

70. Hu X, Paik PK, Chen J, Yarilina A, Kockeritz L, Lu TT, et al. IFN-gamma suppresses IL-10 production and synergizes with TLR2 by regulating GSK3 and CREB/AP-1 proteins. Immunity (2006) 24(5):563-74. doi:10.1016/j. immuni.2006.02.014

71. Berg DJ, Kühn R, Rajewsky K, Müller W, Menon S, Davidson N, et al. Interleukin-10 is a central regulator of the response to LPS in murine models of endotoxic shock and the Shwartzman reaction but not endotoxin tolerance. J Clin Invest (1995) 96(5):2339-47. doi:10.1172/JCI118290

72. Takeda K, Clausen BE, Kaisho T, Tsujimura T, Terada N, Förster I, et al. Enhanced Th1 activity and development of chronic enterocolitis in mice devoid of Stat3 in macrophages and neutrophils. Immunity (1999) 10(1): 39-49. doi:10.1016/S1074-7613(00)80005-9

73. Beurel E, Jope RS. Glycogen synthase kinase-3 promotes the synergistic action of interferon-gamma on lipopolysaccharide-induced IL-6 production in RAW264.7 cells. Cell Signal (2009) 21(6):978-85. doi:10.1016/j.cellsig. 2009.02.019

74. Kai JI, Huang WC, Tsai CC, Chang WT, Chen CL, Lin CF. Glycogen synthase kinase-3beta indirectly facilitates interferon-gamma-induced nuclear factor-kappaB activation and nitric oxide biosynthesis. J Cell Biochem (2010) 111(6):1522-30. doi:10.1002/jcb.22881

75. Ko R, Lee SY. Glycogen synthase kinase 3beta in toll-like receptor signaling. BMB Rep (2016) 49(6):305-10. doi:10.5483/BMBRep.2016.49.6.059

76. Torres BA, Johnson HM. Lipopolysaccharide and polyribonucleotide activation of macrophages: implications for a natural triggering signal in tumor cell killing. Biochem Biophys Res Commun (1985) 131(1):395-401. doi:10.1016/0006-291X(85)91815-7

77. Pace JL, Russell SW, LeBlanc PA, Murasko DM. Comparative effects of various classes of mouse interferons on macrophage activation for tumor cell killing. J Immunol (1985) 134(2):977-81.

78. Matsumoto M, Seya T. TLR3: interferon induction by double-stranded RNA including poly(I:C). Adv Drug Deliv Rev (2008) 60(7):805-12. doi:10.1016/ j.addr.2007.11.005

79. Utaisincharoen P, Anuntagool N, Limposuwan K, Chaisuriya P, Sirisinha S. Involvement of beta interferon in enhancing inducible nitric oxide synthase production and antimicrobial activity of Burkholderia pseudomalleiinfected macrophages. Infect Immun (2003) 71(6):3053-7. doi:10.1128/IAI.71. 6.3053-3057.2003

80. O’Neill LA, Bowie AG. The family of five: TIR-domain-containing adaptors in toll-like receptor signalling. Nat Rev Immunol (2007) 7(5):353-64. doi:10.1038/nri2079

81. Ouyang X, Negishi H, Takeda R, Fujita Y, Taniguchi T, Honda K. Cooperation between MyD88 and TRIF pathways in TLR synergy via IRF5 activation. Biochem Biophys Res Commun (2007) 354(4):1045-51. doi:10.1016/j.bbrc. 2007.01.090 
82. Cai X, Yin Y, Li N, Zhu D, Zhang J, Zhang CY, et al. Re-polarization of tumor-associated macrophages to pro-inflammatory M1 macrophages by microRNA-155. J Mol Cell Biol (2012) 4(5):341-3. doi:10.1093/jmcb/mjs044

Conflict of Interest Statement: The authors declare that the research was conducted in the absence of any commercial or financial relationships that could be construed as a potential conflict of interest.
Copyright (C) 2017 Müller, Christopoulos, Halder, Lunde, Beraki, Speth, Øynebråten and Corthay. This is an open-access article distributed under the terms of the Creative Commons Attribution License (CC BY). The use, distribution or reproduction in other forums is permitted, provided the original author(s) or licensor are credited and that the original publication in this journal is cited, in accordance with accepted academic practice. No use, distribution or reproduction is permitted which does not comply with these terms. 